\title{
Absorption Behaviours of Copper, Lead, and Arsenic in Aqueous Solution Using Date Palm Fibres and Orange Peel: Kinetics and Thermodynamics
}

\author{
Muhammad Tahir Amin ${ }^{1 *}$, Abdulrahman Ali Alazba1, \\ Muhammad Nasir Amin ${ }^{2}$ \\ ${ }^{1}$ Alamoudi Water Research Chair, King Saud University, \\ P.O. Box 2460, Riyadh 11451, Kingdom of Saudi Arabia \\ ${ }^{2}$ Department of Civil and Environmental Engineering, College of Engineering, King Faisal University, \\ P.O. Box 380, Al-Hofuf, Al-Ahsa 31982, Kingdom of Saudi Arabia
}

Received: 5 September 2016

Accepted: 13 November 2016

\begin{abstract}
In this study, date palm fibres and orange peel in both individual and hybrid forms were studied for the removal of copper, lead, and arsenic. Equilibrium was achieved after 150 minutes, and the highest and the lowest removal efficiencies were for $\mathrm{Cu}^{+2}$ and $\mathrm{As}(\mathrm{V})$, respectively. A slightly higher removal efficiency of metal ions using orange peel was observed, which could be due to the greater number of functional groups on the chemically pre-treated adsorbent. The highest removal was observed at $\mathrm{pH} 6$, and the adsorption data exhibited a linear increase in metal removal capacity with increasing adsorbent concentrations from 0.1 to $2 \mathrm{~g} / \mathrm{L}$. A significantly higher removal efficiency was observed for a $45 \mu \mathrm{m}$ particle size compared to larger particle sizes. Additionally, a $30-40 \%$ decrease in removal efficiencies was observed for all three heavy metal ions when using the date palm fibres or the hybrid adsorbent when the initial metal concentrations were increased from 20 to $80 \mathrm{mg} / \mathrm{L}$. The Freundlich model agreed with the experimental data slightly better than the Langmuir model for both date palm fibres and the hybrid adsorbent. A pseudo second-order kinetic model better described the kinetic behaviour of $\mathrm{As}(\mathrm{V})$ adsorption on the investigated adsorbents. Date palm fibres exhibited exothermic adsorption, while both orange peel and the hybrid adsorbent displayed exothermic and endothermic reactions. Increased randomness at the solid-liquid interface was observed for all adsorbents, and the Gibbs free energy change values were negative, confirming the spontaneous nature of adsorption, which proceeded in the forward direction.
\end{abstract}

Keywords: adsorbent, date palm, heavy metals, hybrid, isotherms, orange peel

*e-mail: mtamin@ksu.edu.sa 


\section{Introduction}

Human exposure to waters polluted with even trace levels of heavy metals causes several health problems [1-6]. Polluted water containing heavy metals is of major concern [7], and several conventional methods - including but not limited to chemical precipitation, lime softening [8], and reverse osmosis [9-12] have been employed for heavy metal removal from industrial wastewaters. However, these methods have limitations that include high-energy costs, oxidation by-products, ion exchange regeneration needs, bulk toxic sludge generation in flocculation/coagulation processes, short half-life in ozonation, and membrane fouling during the filtration process. Furthermore, these methods are ineffective for the treatment of high heavy metal concentrations $(100 \mathrm{mg} / \mathrm{L})$ in aqueous solutions [13].

Bulk availability of bioadsorbents, metal selectivity, simplicity of design, ease of operation, automation, operation capabilities at very low concentrations, lower initial costs, and excellent resistance toward degenerative actions of target contaminants are some advantages that make adsorption techniques a favourable approach to metal treatment [13-16]. Many adsorbents, such as Sargassum acinarum [17], grape seeds [18], lentils, wheat and rice shells [19], coconut tree sawdust, eggshells and sugarcane bagasse [20], oyster shell powder [21], black liquor [22], and mushroom biomass [23], have been investigated for copper removal from industrial wastewaters. Innovative hybrid materials with unique physicochemical properties have also been used for the removal of metal ions [24-25]. Activated carbon (AC) adsorbents are commonly used for heavy metal removal from polluted water and are very effective due to their high surface area [26-27]. Dry plants, peat, red mud, fly ash, zeolites, blast furnace slags, hydrotalcites, hydroxides, sawdust, and various biosorbents are also notable materials used for metal treatment [28-31].

Date palm fibres (DPF) have proven to be an efficient adsorbent for heavy metal removal [32-37]. Similarly, several studies on the removal of heavy metals by adsorption on raw and chemically modified orange peel (OP) have been reported [38-40]. Although there are numerous investigations on DPF and OP for the removal of heavy metals, the application of a hybrid DPF and OP material for the removal of heavy metals ions, including $\mathrm{Cu}^{+2}, \mathrm{~Pb}^{+2}$, and $\mathrm{As}(\mathrm{V})$, is investigated for the first time in this study. In addition, a comparison is performed by using the individual adsorbents under different process parameters (i.e., contact time, $\mathrm{pH}$, adsorbent dose, adsorbent size, and initial metal concentrations). Moreover, isotherms, kinetics, and thermodynamics are studied simultaneously by presenting a comparison between the individual and hybrid adsorbents.

\section{Materials and Methods}

\section{Chemicals and Reagents}

A stock solution of $\mathrm{Cu}^{+2}(1000 \mathrm{mg} / \mathrm{L})$ was prepared in deionized water by dissolving $3.917 \mathrm{~g}$ of copper sulphate pentahydrate salt $\left(\mathrm{CuSO}_{4} * 5 \mathrm{H}_{2} \mathrm{O} ; \mathrm{AR}\right.$ grade Merk, Germany) in a $1,000 \mathrm{~mL}$ volumetric flask. Similarly, $\mathrm{PbCl}_{2}$ was used for preparing a stock solution of $\mathrm{Pb}^{+2}$. An arsenate stock solution $(1,000 \mathrm{mg} / \mathrm{L})$ was prepared by dissolving the appropriate amount of sodium arsenate $\left(\mathrm{Na}_{2} \mathrm{HAsO}_{4} .7 \mathrm{H}_{2} \mathrm{O}\right)$ in Millipore water. The stock solutions were preserved by adding $2 \mathrm{~mL}$ of concentrated $\mathrm{HCl}$ and were stored at $4^{\circ} \mathrm{C}$ for long-term use. From the stock solutions, different working standard solutions of initial concentrations in the range of $10-50 \mathrm{mg} / \mathrm{L}$ were prepared for use in the experiments by serial dilution of the $1,000 \mathrm{mg} / \mathrm{L}$ stock solutions with distilled-deionized water. The $\mathrm{pH}$ of the solution was adjusted using $0.1 \mathrm{M} \mathrm{HCl}$ and $0.1 \mathrm{M} \mathrm{NaOH}$ solutions. Measurements of $\mathrm{pH}$ were carried out with a microprocessor-based $\mathrm{pH}$ meter (PHS-3CW China).

\section{Adsorbent Preparation and Pre-Treatment}

Different sections of dry date palm trunks and leaves were collected from various locations in Riyadh, Saudi Arabia. The DPF were woven and pulled out of the trunks in the form of a nearly rectangular mesh formed with superimposed tree layers. When immersed in water, the layers were easily separated into individual fibres of $0.2-0.8 \mathrm{~mm}$ diameter, with an average size of approximately $0.5 \mathrm{~mm}$. Then the DPF were washed three times with tap water followed by thorough rubbing to remove all foreign particles, then filtered and soaked in distilled water for 30 minutes and filtered again. The DPF were placed in a drying oven at $105^{\circ} \mathrm{C}$ for 24 hours, then crushed by a crushing machine and finally stored in airtight containers. The main components of the DPF were $44.17 \%$ cellulose, $21.95 \%$ hemicellulose, and $12.75 \%$ lignin [41], which was also the case in the current study but with cellulose and lignin being $52 \%$ and $15 \%$, respectively.

The orange peel (OP) was washed with distilled water and dried at $70^{\circ} \mathrm{C}$ inside a convection oven for $24 \mathrm{~h}$; then the product was crushed and sieved to obtain an average particle size of approximately $0.5 \mathrm{~mm}$. Finally, both the DPF and OP adsorbents were pre-treated with ethanol and $\mathrm{NaOH}$ (approximately $60 \mathrm{~g}$ of the adsorbent was pretreated in $300 \mathrm{~mL}$ of $1 \% \mathrm{NaOH}$ solution and $300 \mathrm{~mL}$ of ethanol at room temperature, $25^{\circ} \mathrm{C}$, for $24 \mathrm{~h}$ ) and were then modified with mercaptoacetic acid $\left(\mathrm{C}_{2} \mathrm{H}_{2} \mathrm{O}_{2} \mathrm{~S}\right)$ (by stirring approximately $30 \mathrm{~g}$ of the dry product in $1 \mathrm{~L}$ of $1 \%$ mercapto-acetic acid for $12 \mathrm{~h}$ at room temperature, $25^{\circ} \mathrm{C}$ ) to convert the abundant hydroxyl groups into mercapto groups, which have a high affinity for metal ions, thus 
improving their adsorption capacity according to the following reaction:

$$
\mathrm{R}-\mathrm{OH}+\mathrm{HOOCCH}_{2} \mathrm{SH}=\mathrm{R}-\mathrm{OOCCH}_{2} \mathrm{SH}+\mathrm{H}_{2} \mathrm{O}
$$

\section{Batch Adsorption Experiments}

All of the batch experiments were carried out in triplicate at $30^{\circ} \mathrm{C}$ in a set of $100 \mathrm{~mL}$ conical flasks by shaking at $220 \mathrm{rpm}$ in a temperature-controlled Wise Cube Orbital Shaker (Daihan Scientific Co. Ltd, Wisd. ThermoStable IS-20, South Korea) using a fixed mass of 0.5 and $1 \mathrm{~g} / \mathrm{L}$ of each DPF or OP when used individually and $0.5 \mathrm{~g} / \mathrm{L}$ of each DPF and OP for the hybrid adsorbent (i.e., $50 \%$ of each adsorbent in the proposed hybrid adsorbent). A batch experiment to test time to equilibrium was conducted in a range of time intervals from 15 to $180 \mathrm{~min}$ in a solution with an initial $\mathrm{pH}$ of approximately 6 . The effect of the $\mathrm{pH}$ of solution on metal adsorption onto chemically modified DPF and OP was determined in the $\mathrm{pH}$ range of 2-7. The effect of various adsorbent concentrations was observed by using 0.1 and $0.2-2 \mathrm{~g} / \mathrm{L}$ of adsorbent with regular increments of $0.2 \mathrm{~g} / \mathrm{L}$. To determine the effect of the adsorbent particle size on the removal of heavy metal ions, different particle sizes were used in a range of 45-251 $\mu \mathrm{m}$. The effect of the initial metal concentration on adsorption capacity was also analysed in the range of $10-50 \mathrm{mg} / \mathrm{L}$. Table 1 describes the variables and constants of each experiment used in this study.

After shaking, the samples were centrifuged (Elektromag M815P model) at 1,000 rpm for 5 minutes to separate the adsorbate from the solution and were then filtered using nitrocellulose filter paper $(0.45 \mu \mathrm{m})$ using a vacuum filtration assembly. The residual metal concentration in the filtrate was measured using a flame atomic absorption spectrometer (AAS), while the As(V) concentrations in the samples were measured using an AAS (Perkin Elmer AAnalist 200) equipped with a manual hybrid generator at $188.9 \mathrm{~nm}$. The capacity of adsorbed copper was calculated using Eq. (1).

$$
q_{e}=\left(C_{o}-C_{f}\right) V / M
$$

... where $\mathrm{q}_{\mathrm{e}}$ is the metal uptake $(\mathrm{mg} / \mathrm{g}), \mathrm{C}_{\mathrm{o}}(\mathrm{mg} / \mathrm{L})$ and $\mathrm{C}_{\mathrm{f}}$ $(\mathrm{mg} / \mathrm{L})$ are the initial and final metal concentrations in the solution, respectively, and V (L) and $\mathrm{M}(\mathrm{g})$ are the solution volume and mass of the adsorbent, respectively. The percentage of the metal ions removed can be calculated using Eq. (2).

$$
\text { Removal }(\%)=\frac{\left(C_{o}-C_{f}\right)}{C_{o}} * 100
$$

\section{Isotherms and Kinetic Models}

Adsorption isotherms are of great importance in designing any adsorption system for wastewater treatment. Out of different isotherm models, Langmuir and Freundlich were used to fit the adsorption kinetic data for determining the best-fit. The mechanism of adsorption onto the surface of adsorbents was also investigated using pseudo first-order and pseudo second-order reaction models.

\section{Results and Discussion}

\section{Surface Characterizations of Adsorbents}

The characterization of DPF and OP $(45-251 \mu \mathrm{m})$ before and after adsorption of heavy metal ions was performed using scanning electron microscopy (SEM) analysis. Different samples were mounted on brass stubs using double-sided adhesive tape. SEM photographs were taken with a scanning electron microscope (TESCAN VEGA 3 SBU USA) at various magnifications from $\times 500$ to $\times 12,000$. SEM analysis was carried out to obtain insight into how the surfaces of DPF and OP look before and after the adsorption of heavy metal ions (Fig. 1).

SEM photographs showed asymmetric pores that were rough and cylinders on the surface of the DPF fibres before the adsorption of heavy metal ions. The rough surface of these asymmetric pores helps improve the interaction with the heavy metal ions. After adsorption of heavy metal ions $\left(\mathrm{Cu}^{+2}\right.$, for example, in Fig. $\left.1 \mathrm{~b}\right)$, the surface of DPF becomes smooth and shiny with closed pore structures, possibly due to the physico-chemical interaction between the functional groups present on the surface of DPF and the heavy metal ions.

In addition, Fourier transform infrared (FTIR) spectroscopy was carried out to characterize the surface chemistry and the possible functional groups that may
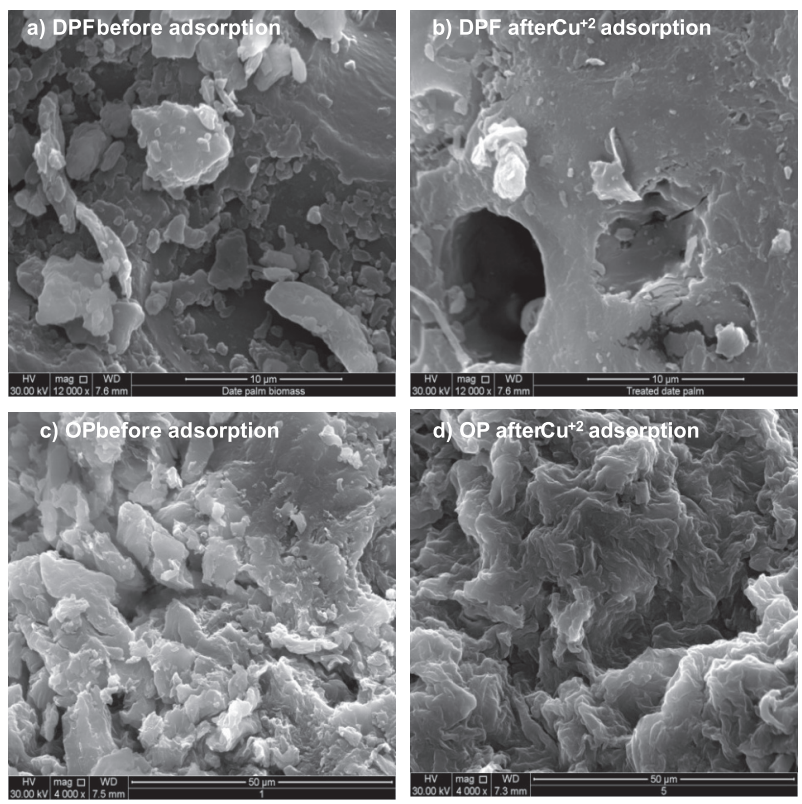

Fig. 1. SEM photographs of DPF and OP before and after $\mathrm{Cu}^{+2}$ adsorption at different magnifications. 

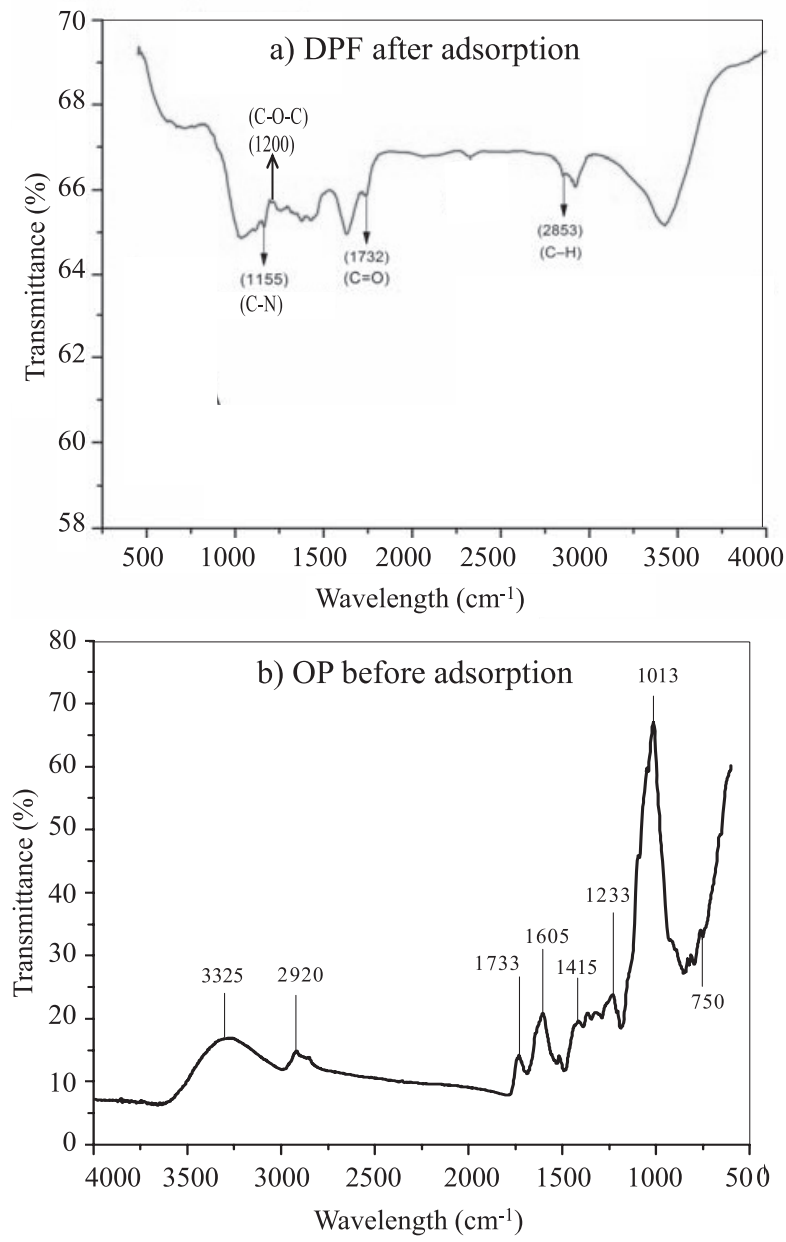

Fig. 2. FTIR spectra of a) DPF after adsorption, and b) OP before adsorption, in the 500 to $4,000 \mathrm{~cm}^{-1}$ wavenumber region.

participate in adsorption. Fig. 2 reflects the various functional groups present on the surface of DPF and OP before and after adsorption of heavy metal ions $\left(\mathrm{Cu}^{+2}\right)$, respectively.

After adsorption of heavy metal ions $\left(\mathrm{Cu}^{+2}\right.$, for example, in Fig. 2a) on the surface of DPF, a sharp peak at $2,853 \mathrm{~cm}^{-1}$ demonstrates the existence of aldehyde groups. At equilibrium adsorption, the involvement of unsaturated esters and hydroxyl groups $\left(\mathrm{Si}^{18} \mathrm{OH}\right)$ for the adsorption of $\mathrm{Cu}^{+2}$ is noticed due to the disappearance of two peaks at 1,732 and $3,738 \mathrm{~cm}^{-1}$ [42]. The formation of new bonds between the functional groups on the adsorbent surface and adsorbate in solution was seen owing to the shift in vibration frequencies [43], as reported for dye removal using sugarcane bagasse in one of studies [44].

In OP adsorbent, peaks around $3,325 \mathrm{~cm}^{-1}$ can be assigned to $\mathrm{O}-\mathrm{H}$ stretching due to inter- and intramolecular hydrogen bonding of polymeric compounds and carboxylic acids showing the presence of "free" hydroxyl groups on the adsorbent surface [45]. The peak at $1,739 \mathrm{~cm}^{-1}$ is due to the stretching vibration of the bond due to non-ionic carboxyl groups, and could be assigned to carboxylic acids or their esters [46]. The strong band at 1,013 and $1,033 \mathrm{~cm}^{-1}$ can be allocated to the $\mathrm{C}-\mathrm{O}$ of alcohols and carboxylic acids [46]. The peaks between $1,014-750 \mathrm{~cm}^{-1}$ are due to the vibration of $\mathrm{C}-\mathrm{O}-\mathrm{C}, \mathrm{C}-\mathrm{O}-\mathrm{P}$ and $\mathrm{O}-\mathrm{H}$ of polysaccharides [38].

\section{Effects of Different Process Parameters on Adsorption}

The results in this section present the potential of DPF and OP as individual adsorbents and as a hybrid material (50\% each) for $\mathrm{Cu}^{+2}, \mathrm{~Pb}^{+2}$, and $\mathrm{As}(\mathrm{V})$ removal. We investigated the effects of contact time, $\mathrm{pH}$, adsorbent concentration, and initial adsorbate and metal concentrations on adsorption capacity and removal efficiency.

\section{Effect of Contact Time on Metal Adsorption}

Kinetic experiments were conducted in triplicate to determine the time required for adsorption equilibrium of all three metals onto DPF, OP, and DPF+OP (Figs 3 and 4). As described in Table 1, a pH of 5 was used for an initial metal concentration of $20 \mathrm{mg} / \mathrm{L}$ in each case. The adsorbent dose and the size of the particles were set at 0.5 $\mathrm{g} / \mathrm{L}$ and $152 \mu \mathrm{m}$, respectively.

The data reflected a significantly higher adsorption capacity of all three metal ions after approximately 90
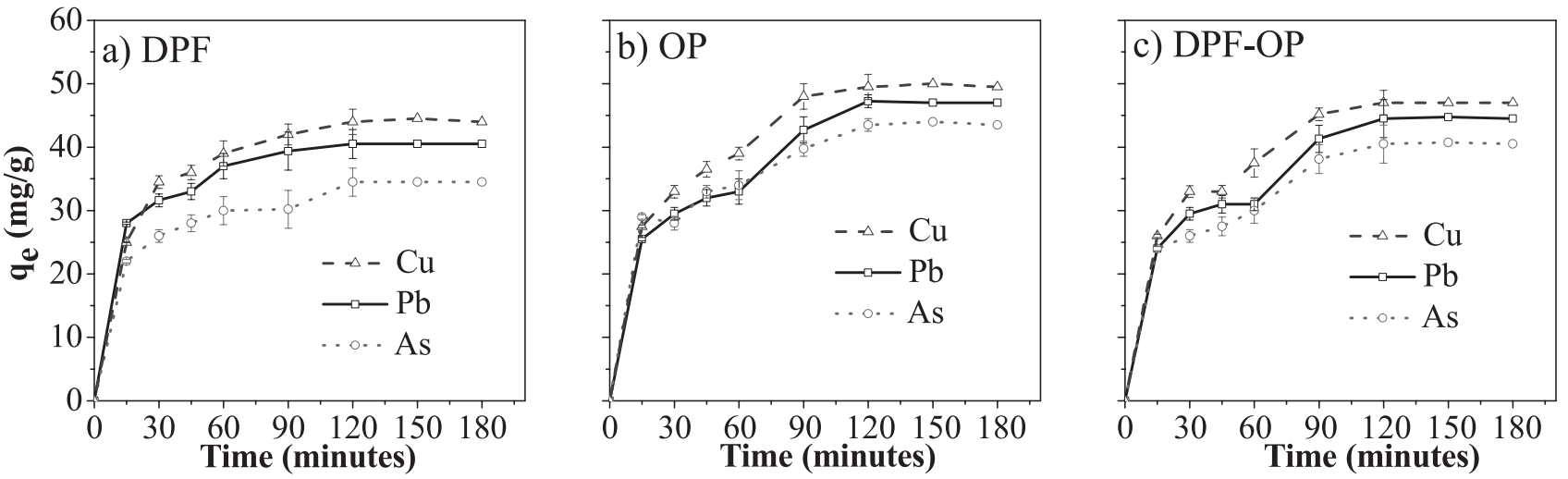

Fig. 3. Effects of contact time on heavy metal adsorption capacity of a) DPF, b) OP, and c) DPF+OP. 

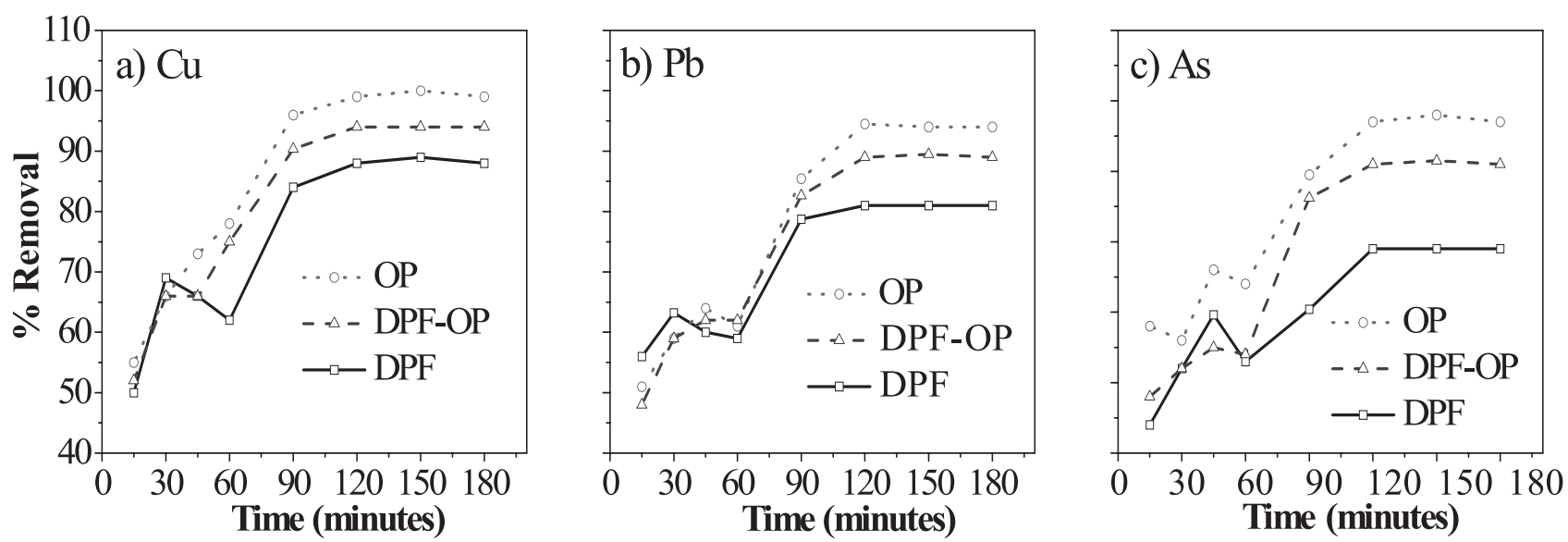

Fig. 4. Effects of contact time on the removal efficiency of different adsorbents for a) $\mathrm{Cu}^{+2}$, b) $\mathrm{Pb}^{+2}$, and c) $\mathrm{As}(\mathrm{V})$.

minutes, and a slower metal uptake was observed for the next half hour up to 120 minutes. After an initially high adsorption for approximately 15 minutes, a nearly constant high adsorption capacity was observed from 60 to 90 minutes. It was evident that no considerable changes in metal adsorption capacity were seen after approximately 120 minutes, and equilibrium was achieved after approximately 150 minutes.

The kinetics of metal sorption determine residence time and are an important characteristic defining the efficiency of an adsorbent [47]. Sorption kinetics are controlled by several independent processes, such as bulk diffusion, external mass transfer, chemical reactions, and intra-particle diffusion [48].

From the trends presented in Figs 3 and 4, the adsorptions of all three metals were predicted to occur quite rapidly initially, and most were adsorbed in under one hour. The adsorption rate becomes slower over time, in the range of 1 to 2 hours. Furthermore, the percentage removal of $\mathrm{Cu}^{+2}$ was higher than that of $\mathrm{Pb}^{+2}$, while $\mathrm{As}(\mathrm{V})$ had the lowest percentage removal with all types of adsorbents. Keeping in mind the dependency of adsorption on surface area [49], the faster removal efficiency during the first hour could initially be attributed to adsorbent availability of the uncovered surface area. A slightly higher removal efficiency of metal ions using OP could be due to increased functional groups on the modified adsorbents and chemical pre-treatment of these adsorbents [50].

\section{Effects of Solution $\mathrm{pH}$}

The effects of $\mathrm{pH}(5-10)$ on the adsorption of studied heavy metals ions of $\mathrm{Pb}^{+2}$ and $\mathrm{As}(\mathrm{V})$ by the adsorbents are shown in Figs 5 and 6. Batch experiments were conducted for initial metals concentrations $(50 \mathrm{mg} / \mathrm{L})$, adsorbent dose $(1 \mathrm{~g} / \mathrm{L})$, and size of the particle $(152 \mu \mathrm{m})$ over 120 minutes of contact time (Table 1). Unlike other metal ions, $\mathrm{Cu}^{+2}$ precipitates at $\mathrm{pH} 5$ and above, so the comparison was performed for $\mathrm{Pb}^{+2}$ and $\mathrm{As}(\mathrm{V})$ (Figs 5 and 6), which do not precipitate at higher $\mathrm{pH}$ values as well.

The results reflected the intermediate adsorption of $\mathrm{Pb}^{+2}$ onto the DPF and OP hybrid adsorbent (Fig. 5c) compared with $\mathrm{As}(\mathrm{V})$ and compared DPF alone, which showed the lowest adsorption capacity, and compared OP alone, which showed the highest adsorption capacity. The capacity of metal adsorption increased by increasing the initial $\mathrm{pH}$ solution from 3 to 5 or up to 6 in some cases, like when using OP and the hybrid adsorbent for As(V) and when using $\mathrm{OP}$ for $\mathrm{Pb}^{+2}$ only. Furthermore, the highest uptake was observed at a $\mathrm{pH}$ of 5-6 in most cases, except when using DPF alone - when the optimum $\mathrm{pH}$ range could be as high as $7-8$ but for $\mathrm{Pb}^{+2}$ only (Fig. 5a).

Table 1. Variable parameters and constants used in different experimental types.

\begin{tabular}{|c|c|c|c|c|c|c|c|}
\hline \multicolumn{2}{|c|}{ Variable parameters } & \multicolumn{2}{|c|}{ Value/Range } & Unit & \multicolumn{3}{c|}{ Values of constants for different experimental types } \\
\hline \multicolumn{2}{|c|}{} & \multicolumn{2}{|c|}{$\begin{array}{c}\text { Contact } \\
\text { time }\end{array}$} & $\mathrm{pH}$ & $\begin{array}{c}\text { Initial metal } \\
\text { conc. }\end{array}$ & $\begin{array}{c}\text { Adsorbent } \\
\text { dose }\end{array}$ & $\begin{array}{c}\text { Particle } \\
\text { size }\end{array}$ \\
\hline Contact time & $\begin{array}{c}15,30,45,60,90,120, \\
150,180\end{array}$ & minutes & $\mathrm{X}$ & 5 & 50 & 0.5 & 152 \\
\hline $\mathrm{pH}$ & $5-10 @ 1$ & & 120 & $\mathrm{X}$ & 50 & 1 & 152 \\
\hline Initial metal concentration & $20-80 @ 20$ & $\mathrm{mg} / \mathrm{L}$ & 60 & 5 & $\mathrm{X}$ & 1 & 200 \\
\hline Initial adsorbent dose & $0.1,0.2-2 @ 0.2$ & $\mathrm{~g} / \mathrm{L}$ & 120 & 5 & 50 & & $\mathrm{X}$ \\
\hline Particle size & $45,75,105,152,178$, & $\mu \mathrm{m}$ & 120 & 5 & 50 & 0.5 & $\mathrm{X}$ \\
\hline
\end{tabular}



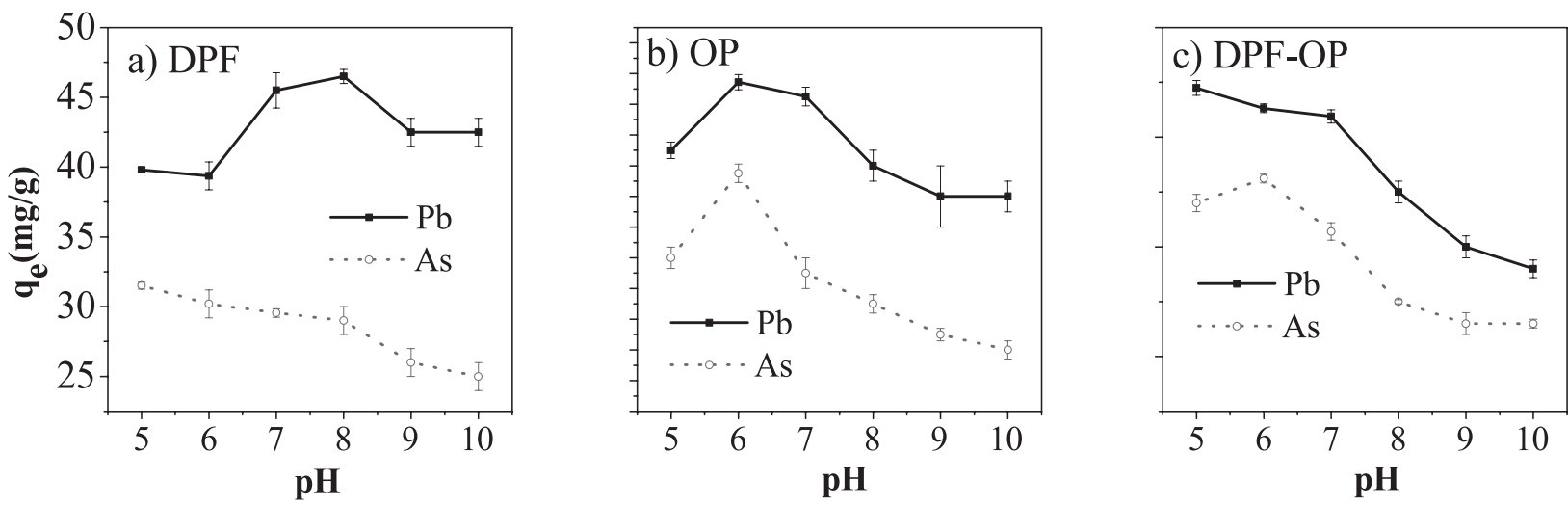

Fig. 5. Effects of $\mathrm{pH}$ on the metal adsorption capacity of a) DPF, b) OP, and c) DPF+OP.

$\mathrm{pH}$ is one the most important mechanisms governing adsorption processes [51]. Higher uptake at relatively low acid conditions confirms the interference of $\mathrm{H}^{+}$ions and increased electrostatic repulsive interactions, resulting in the lowest adsorption at high $\mathrm{pH}$ values [52-53].

\section{Effects of the Initial Adsorbent Concentration}

Figs 7 and 8 depict changes in metal removal capacity and percentage removal, respectively, by varying the initial adsorbent concentrations. The adsorbent concentrations varied $(0.1$ and $0.2-2$ at a regular interval of $0.2 \mathrm{~g} / \mathrm{L})$, and the rest of the experimental variables were constant $(\mathrm{pH}$ 5.0 , initial metal concentration of $50 \mathrm{mg} / \mathrm{L}$, particle size of $251 \mu \mathrm{m}$, and contact time of $120 \mathrm{~min}$ ).
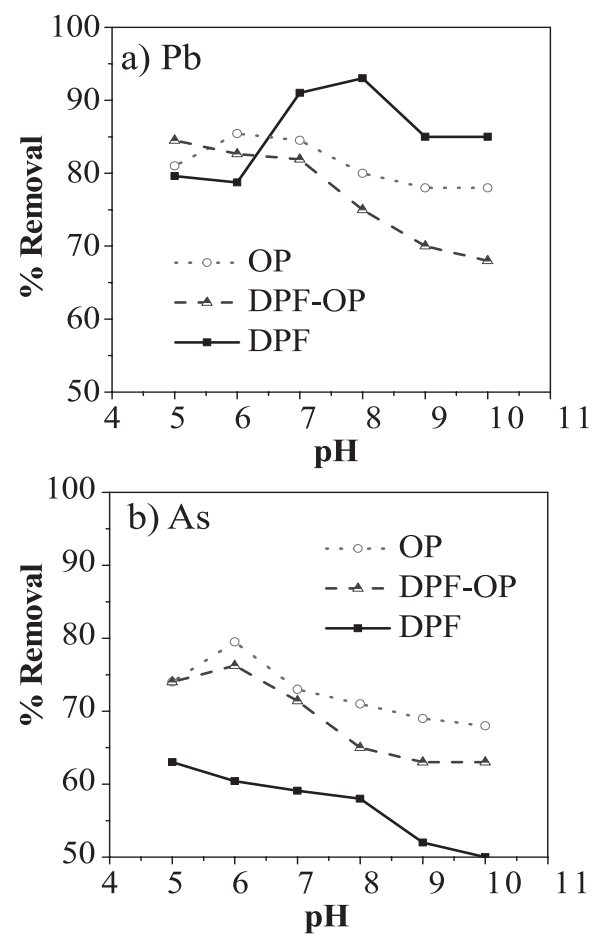

Fig. 6. Effects of $\mathrm{pH}$ on the removal efficiency of different adsorbents for a) $\mathrm{Pb}^{+2}$ and b) $\mathrm{As}(\mathrm{V})$.
The adsorption data revealed a linear increase in the metals' adsorption capacities with an increasing adsorbent concentration up to $2 \mathrm{~g} / \mathrm{L}$ (Fig. 7). Possible reasons could be increased surface area and available binding sites, or increased functional groups resulting from an increased initial amount of adsorbent [17]. Once again, the $\mathrm{Cu}^{+2}$ adsorption capacity was the highest, while the lowest uptake was observed for As(V), as shown in Fig. 7.

Slightly better results were achieved when using OP, but only when compared with DPF and the hybrid adsorbent (Fig. 8). This could be because OP primarily consists of cellulose, pectin, hemicellulose, chlorophyll pigments, and other low molecular weight hydrocarbons, with larger surface areas, higher swelling capacities, and outstanding mechanical strength compared to DPF.

\section{Effects of Particle Size}

Particles of modified DPF, OP, and the DPF and OP hybrid that ranged in size from $45-251 \mu \mathrm{m}$ were used to determine the effects of different particle sizes on metal removal, as shown in Figs 9 and 10. A pH value of 5 was used in batch experiments for initial metal concentrations of $50 \mathrm{mg} / \mathrm{L}$, adsorbent concentration of $0.5 \mathrm{~g} / \mathrm{L}$ and contact time of 120 minutes (Table 1).

As shown in Fig. 9, significantly higher adsorption capacities (nearly $50 \mathrm{mg} / \mathrm{g}$ for both $\mathrm{Cu}^{+2}$ and $\mathrm{Pb}^{+2}$, especially when using OP) were observed with $45 \mu \mathrm{m}$ particle sizes compared to the largest particle size (251 $\mu \mathrm{m})$. A nearly $10 \%$ higher $\mathrm{Cu}^{+2}$ uptake was observed with particle sizes of $45 \mu \mathrm{m}$ compared to $\mathrm{As}(\mathrm{V})$ when using DPF and the hybrid adsorbent (Figs 9a and 9c). This difference, however, was reduced to only $2-3 \%$ in the case of OP (Fig. 9b), indicating that this adsorbent can be considered equally effective for $\mathrm{As}(\mathrm{V})$ uptake as for the other metals.

As can be observed from the results presented in Fig. 10 , removal efficiency decreased by $40-60 \%$ by increasing the size of the adsorbent from $45 \mu \mathrm{m}$ to $251 \mu \mathrm{m}$. The high adsorption of heavy metal ions on the surface of adsorbents due to the small size of the adsorbent leads to the high removal efficiency. The decreased adsorption capacity of adsorbents due to the increased size of the adsorbent 

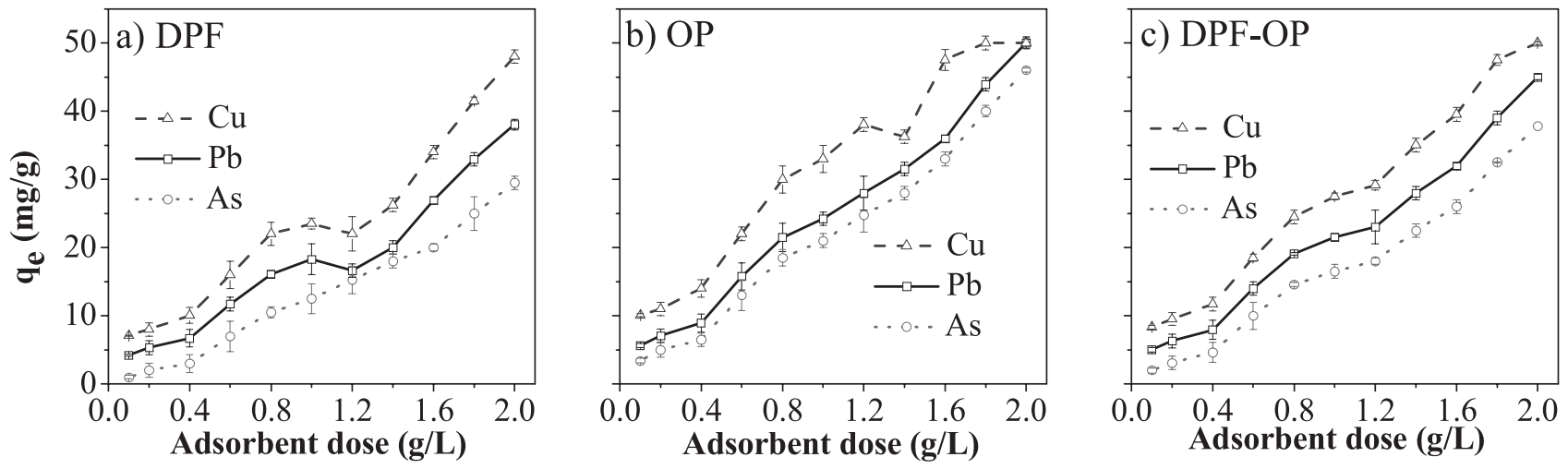

Fig. 7. Effects of adsorbent concentration on metal adsorption capacity of a) DPF, b) OP, and c) DPF+OP.
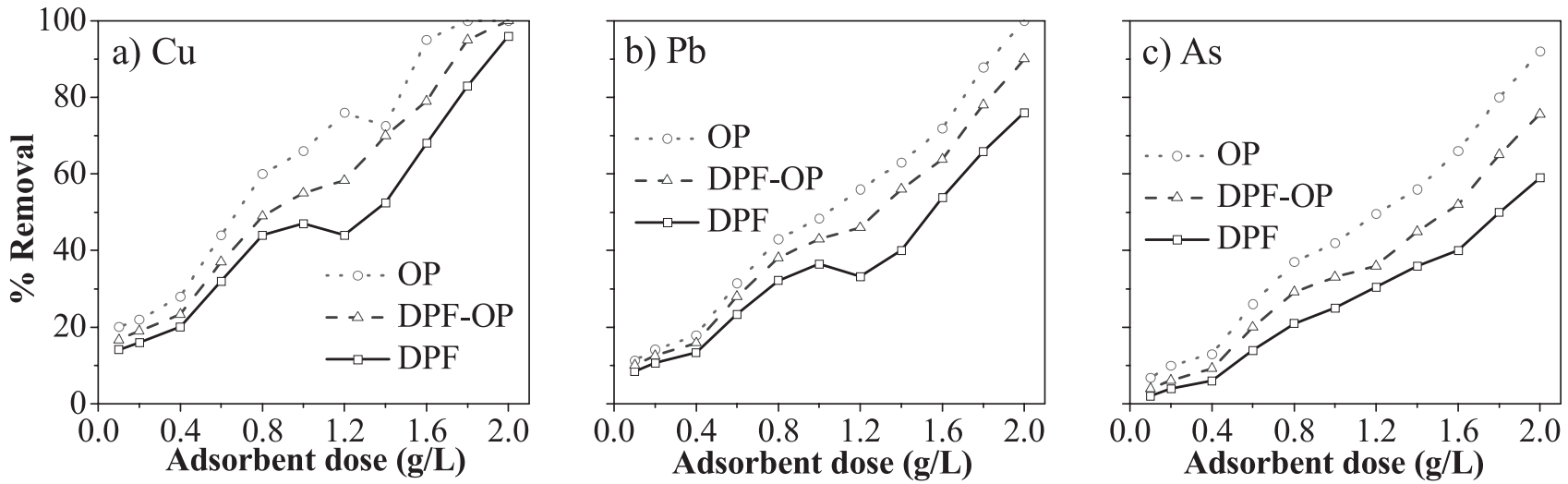

Fig. 8. Effects of adsorbent dose on the removal efficiencies of different adsorbents for a) $\left.\mathrm{Cu}^{+2}, \mathrm{~b}\right) \mathrm{Pb}^{+2}$, and c) $\mathrm{As}(\mathrm{V})$.

results in less removal efficiency because smaller-sized particles offer larger surface areas to metal ions present in the aqueous solution [54].

\section{Effects of Initial Metal Concentrations}

Finally, the adsorption of the chemically modified DPF and OP and the hybrid adsorbent were monitored for initial metal concentrations of $\mathrm{Cu}^{+2}, \mathrm{~Pb}^{+2}$, and $\mathrm{As}(\mathrm{V})$ ranging from $20-80 \mathrm{mg} / \mathrm{L}$, as shown in Figs 11 and 12.
Batch experiments were performed at a $\mathrm{pH}$ of 5 using a particle size of $200 \mu \mathrm{m}$ and adsorbent concentration of $1 \mathrm{~g} / \mathrm{L}$ over 60 minutes of contact time, as described earlier in Table 1.

The amount of metal ions adsorbed at equilibrium increased by approximately $17 \mathrm{mg} / \mathrm{g}$ for $\mathrm{Cu}^{+2}, \mathrm{~Pb}^{+2}$, and $\mathrm{As}(\mathrm{V})$ when using DPF while increasing the initial metal concentration from 20 to $80 \mathrm{mg} / \mathrm{L}$ (Fig. 11a). An increase in the adsorption capacity of approximately $20-25 \mathrm{mg} / \mathrm{g}$ for all heavy metal ions was recorded for the hybrid adsorbent (i.e., DPF-OP) and OP adsorbent by increasing the initial metal
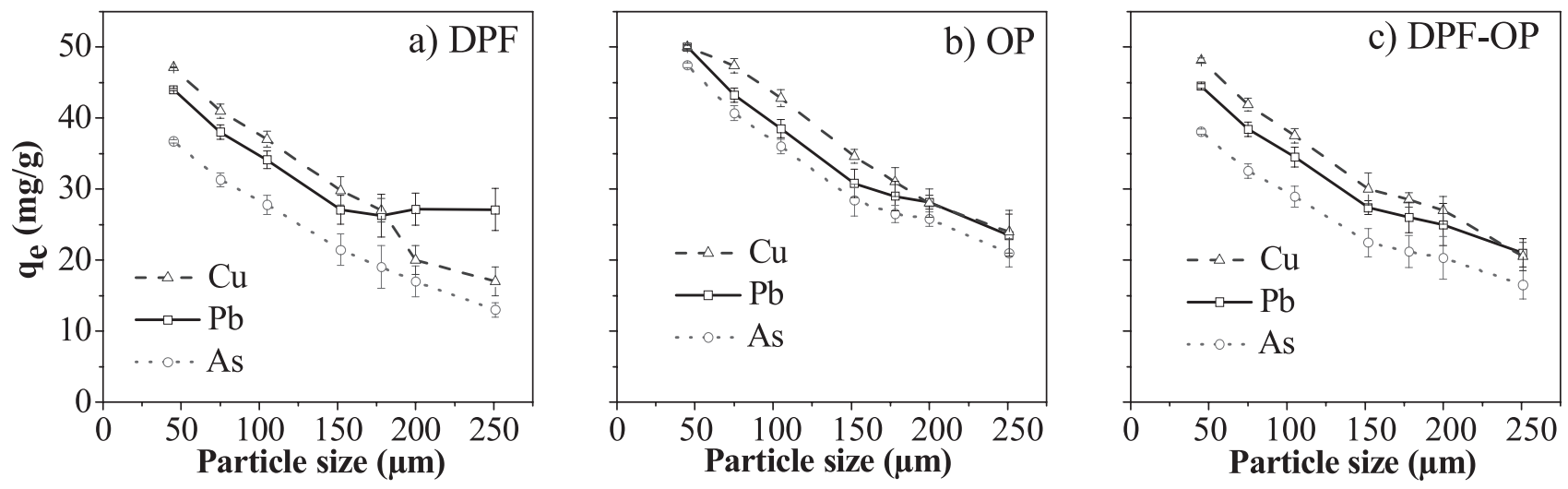

Fig. 9. Effects of particle size on the metal adsorption capacity of a) DPF, b) OP, and c) DPF+OP. 

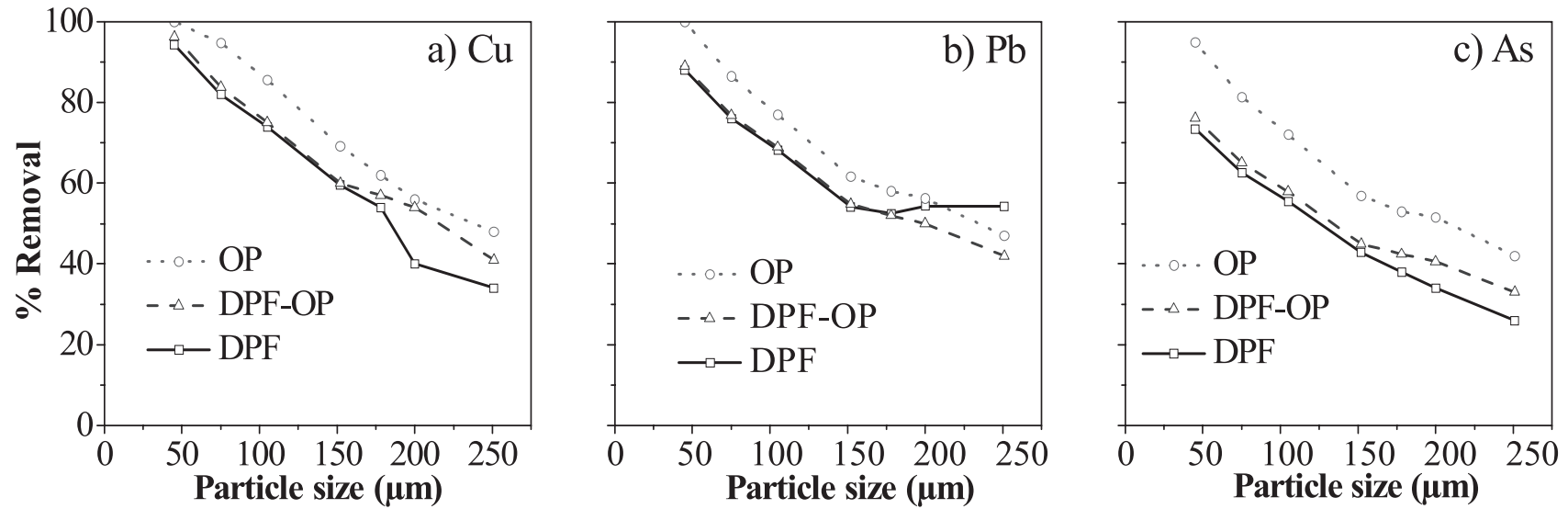

Fig. 10. Effects of particle size on the removal efficiency of different adsorbents for a) $\left.\mathrm{Cu}^{+2}, \mathrm{~b}\right) \mathrm{Pb}^{+2}$, and c) $\mathrm{As}(\mathrm{V})$.

concentration by the same amount, i.e., 20 to $80 \mathrm{mg} / \mathrm{g}$ (Figs $11 \mathrm{~b}$ and $11 \mathrm{c})$. This likely could be attributed to the driving force of the concentration gradient resulting from increased initial metal concentrations, which likely overcame the mass transfer resistance to the adsorbent surface.

The metal removal efficiency, however, decreased by approximately $30-40 \%$ by increasing the initial metal concentration from 20 to $80 \mathrm{mg} / \mathrm{L}$, as seen from the changing trends presented in Fig. 12. The decrease in removal efficiency was only approximately $20 \%$ for As(V) when using DPF only. On the other hand, a maximum decrease of approximately $40 \%$ was observed for both $\mathrm{Pb}^{+2}$ and $\mathrm{As}(\mathrm{V})$ when OP was used. The overall removal efficiency decreased when the initial metal concentrations increased, which could be due to saturation at sorption sites on the surface of the adsorbent [20,55]. Finally, the
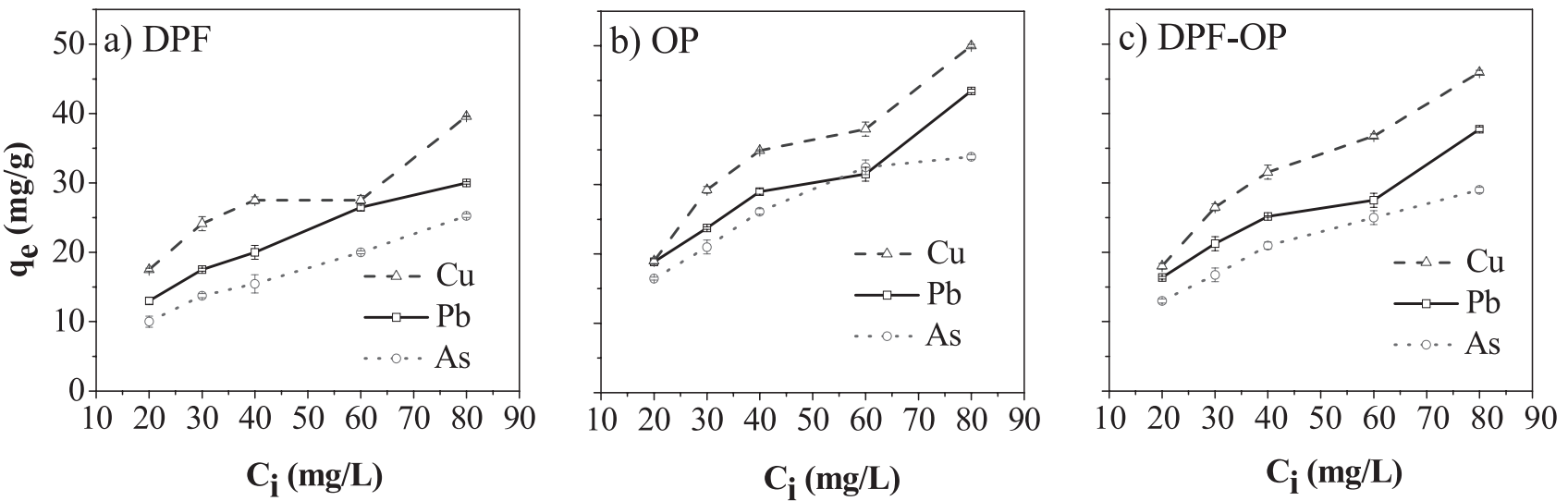

Fig. 11. Effects of initial metal concentrations on the metal adsorption capacity of a) DPF, b) OP, and c) DPF+OP.
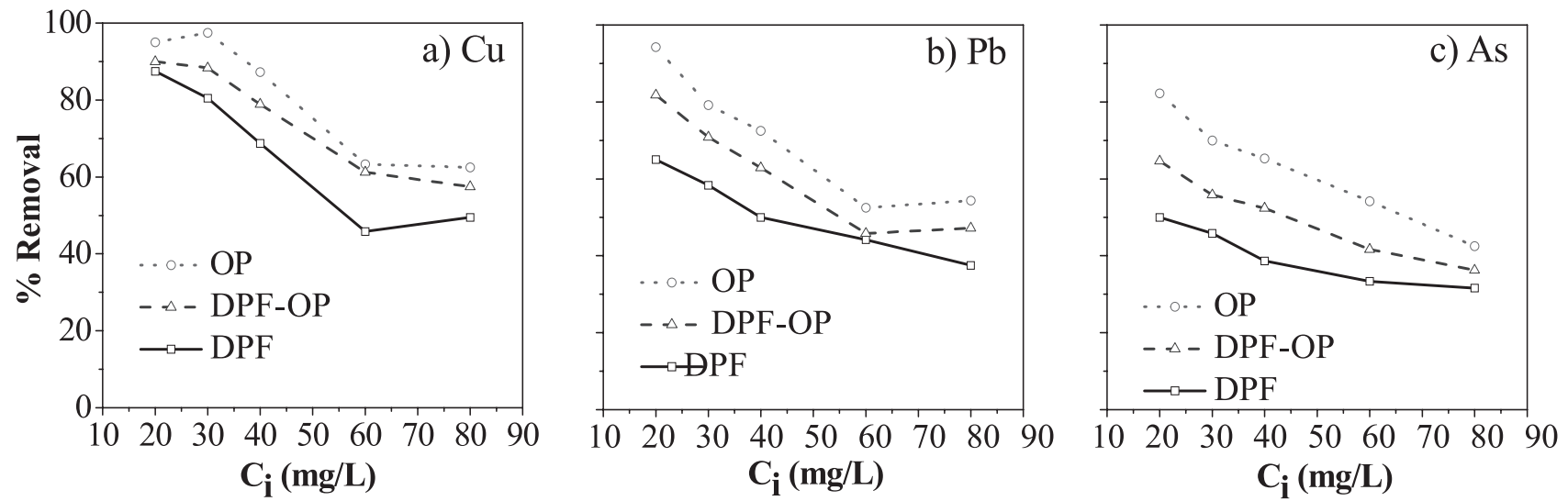

Fig. 12. Effects of initial metal concentration on the removal efficiency of different adsorbents for a) $\left.\mathrm{Cu}^{+2}, \mathrm{~b}\right) \mathrm{Pb}^{+2}$, and c) $\mathrm{As}(\mathrm{V})$. 
relatively faster adsorption of $\mathrm{Cu}^{+2}$ and its higher removal percentage compared to $\mathrm{Pb}^{+2}$ and $\mathrm{As}(\mathrm{V})$ when using DPF could only be attributed to smaller ionic radii, which may diffuse more quickly through the adsorbent pores than the other metals.

\section{Equilibrium Isotherms and Kinetics}

The experimental data for heavy metal ions adsorption was further analysed using the Langmuir and Freundlich isotherm models to describe the adsorption of the solutes $[54,56-57]$. The analysis was carried out at $30^{\circ} \mathrm{C}, \mathrm{pH}=5$, adsorbent concentration of $1 \mathrm{~g} / \mathrm{L}$ for $80 \mathrm{mg} / \mathrm{L}$ initial metal ion concentration, and a duration of $1 \mathrm{~h}$ (only the data for $\mathrm{As}(\mathrm{V})$ for all three adsorbents are presented).

The Langmuir model (Eq. (3)) assumes monolayer coverage, while the Freundlich isotherm (Eq. (4)) assumes multilayer adsorption and is used to describe the adsorption of a heterogeneous system.

$$
\begin{gathered}
q_{e}=\left(q_{\max } K_{a d s} C_{e}\right) / 1+K_{a d s} C_{e} \\
q_{e}=K_{F} C_{e}^{1 / n}
\end{gathered}
$$

...where $\mathrm{q}_{\mathrm{e}}(\mathrm{mg} / \mathrm{g})$ is the amount of metal ions adsorbed at equilibrium, $\mathrm{C}_{\mathrm{e}}(\mathrm{mg} / \mathrm{L})$ is the metal ion concentration in solution, $\mathrm{q}_{\max }$ is the maximum metal concentration attained in monolayer coverage, $\mathrm{K}_{\mathrm{ads}}(\mathrm{L} / \mathrm{mg})$ is the Langmuir adsorption constant, and $\mathrm{K}_{\mathrm{F}}$ and $1 / \mathrm{n}$ indicate the relative adsorption capacity and the heterogeneity factor (adsorption intensity) in the Freundlich isotherm model. The linearized forms of both the Langmuir and Freundlich models can be written as Eqs. (5) and (6), respectively.

$$
\begin{gathered}
\frac{1}{q_{e}}=\frac{1}{q_{\max }}+\left(\frac{1}{q_{\max } K_{a d s}}\right) \frac{1}{C_{e}} \\
\log q_{e}=\log K_{F}+\frac{1}{n} \log C_{e}
\end{gathered}
$$

The fit of the equilibrium data to the Langmuir and Freundlich isotherms was evaluated using plots of $1 / \mathrm{q}_{\mathrm{e}} \sim 1 / \mathrm{C}_{\mathrm{e}}$ and $\log \mathrm{q}_{\mathrm{e}} \sim \log \mathrm{C}_{\mathrm{e}}$, respectively, as shown in Fig. 13. Both $\mathrm{q}_{\max }$ and $\mathrm{K}_{\text {ads }}$ for the Langmuir model can be calculated using the intercept and slope values in the plot of $1 / \mathrm{q}_{\mathrm{e}} \sim 1 / \mathrm{C}_{\mathrm{e}} \cdot \mathrm{K}_{\mathrm{F}}$ and $1 / \mathrm{n}$ in the Freundlich model can be calculated using the same parameters in the linear plot of $\log \mathrm{q}_{\mathrm{e}} \sim \log \mathrm{C}_{\mathrm{e}}$ (Table 2). The maximum adsorption capacity $\left(\mathrm{q}_{\mathrm{m}}, \mathrm{mg} / \mathrm{g}\right)$ in the Freundlich isotherm model, as presented in Table 3, can be determined by operating with constant initial concentration $\mathrm{C}_{0}$ and variable adsorbent doses and can be expressed using Eq. (7).

$$
\frac{t}{q_{t}}=\frac{1}{k_{2} q_{e}^{2}}+\frac{1}{q_{e}} t
$$

The predicted maximum adsorption capacities $\left(\mathrm{q}_{\max }\right.$ and $\mathrm{q}_{\mathrm{m}}$ in the Langmuir and Freundlich isotherm models, respectively) were higher than the experimentally attained values for all three adsorbents. This might be an indication of the saturation capacity of these adsorbents at higher initial $\mathrm{As}(\mathrm{V})$ concentrations (Table 2). The difference was considerable for DPF and OP in the Langmuir and Freundlich isotherm models, as shown in Table 2.

The adsorption isotherms (data shown for As(V) only) agreed with the Freundlich model slightly better than the Langmuir model for both DPF and the hybrid adsorbent because the coefficient of determination $\left(\mathrm{R}^{2}\right)$ is slightly greater in the Freundlich model than in the Langmuir model, as shown in Fig. 13 and Table 2. In addition, the values of $1 / \mathrm{n}$ or $\mathrm{n}$ (less than 1 or in the range of $2-10$ ) determined with the Freundlich isotherm model describe favourable adsorption of $\mathrm{As}(\mathrm{V})$ on both DPF and the hybrid adsorbent [58-59]. The relatively higher $\mathrm{R}^{2}$ value of the Langmuir model compared to the Freundlich model represents better adsorption of $\mathrm{As}(\mathrm{V})$ on $\mathrm{OP}$, which also confirms that a fixed number of adsorption sites were available on this adsorbent. The maximum adsorption capacities for the chemically pre-treated hybrid adsorbent ranged correspondingly with DPF and OP, with the latter being the highest (Table 2). Pre-treated hybrid materials as well as individual adsorbents in this study displayed higher adsorption capacities compared to previous studies
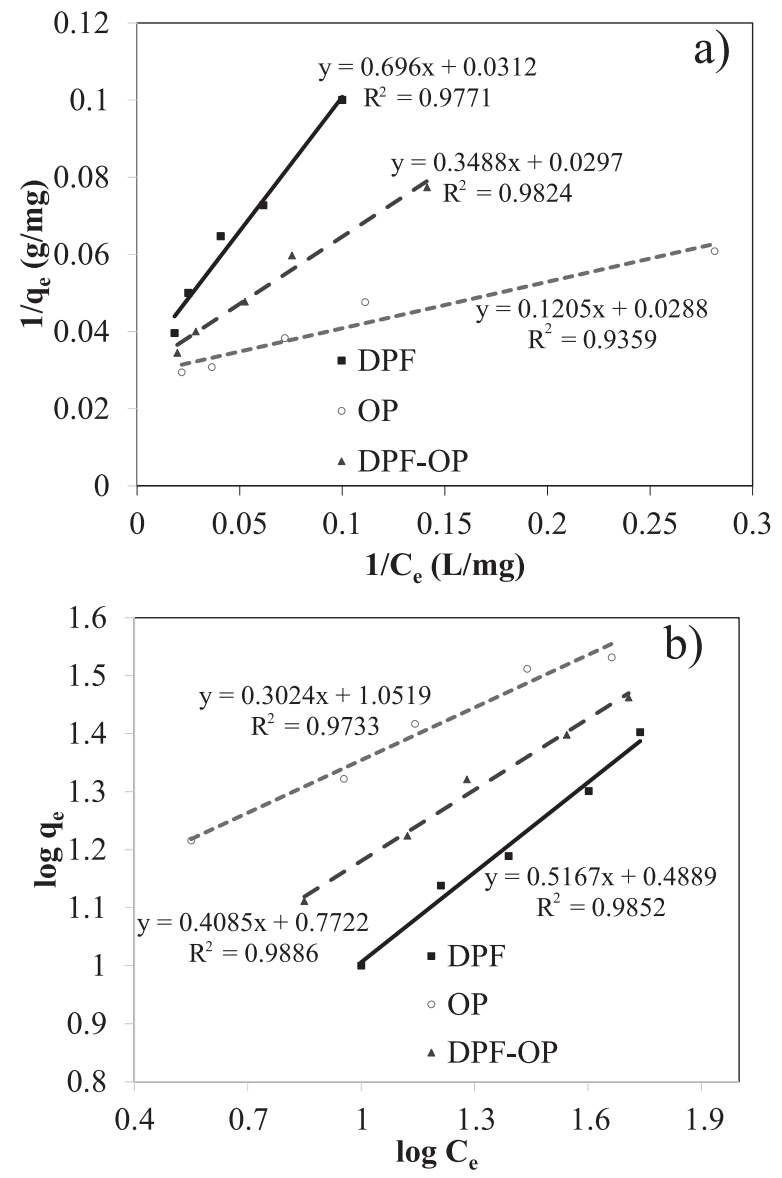

Fig. 13. Adsorption of As(V) on individual and hybrid adsorbents: a) Langmuir isotherm, b) Freundlich isotherm at $80 \mathrm{mg} / \mathrm{L}$ initial concentration of $\mathrm{As}(\mathrm{V})$. 
Table 2. Constants for the Langmuir and Freundlich isotherm models at $80 \mathrm{mg} / \mathrm{L}$ initial concentration of As(V).

\begin{tabular}{|c|c|c|c|c|}
\hline & Parameter & DPF & OP & DPF-OP \\
\hline Experiment & $\mathrm{q}_{\mathrm{e}}(\mathrm{mg} / \mathrm{g})$ & 25 & 34 & 29 \\
\hline \multirow{4}{*}{$\begin{array}{c}\text { Langmuir } \\
\text { isotherm }\end{array}$} & $\left.\mathrm{q}_{\max } \mathrm{mg} / \mathrm{g}\right)$ & 32.05 & 34.72 & 33.67 \\
\cline { 2 - 5 } & $\mathrm{K}_{\mathrm{ads}}(\mathrm{L} / \mathrm{mg})$ & 0.045 & 0.239 & 0.085 \\
\cline { 2 - 5 } & $\mathrm{R}^{2}$ & 0.977 & 0.982 & 0.936 \\
\hline \multirow{4}{*}{$\begin{array}{c}\text { Freundlich } \\
\text { isotherm }\end{array}$} & $1 / \mathrm{n}$ & 0.5167 & 0.3024 & 0.4085 \\
\cline { 2 - 5 } & $\mathrm{n}$ & 1.935 & 3.307 & 2.448 \\
\cline { 2 - 5 } & $\mathrm{K}_{\mathrm{F}}(\mathrm{L} / \mathrm{g})$ & 3.043 & 11.210 & 5.811 \\
\cline { 2 - 5 } & $\mathrm{q}_{\mathrm{m}}(\mathrm{mg} / \mathrm{g})$ & 29.284 & 42.180 & 34.809 \\
\cline { 2 - 5 } & $\mathrm{R}^{2}$ & 0.985 & 0.973 & 0.989 \\
\hline
\end{tabular}

in which pomegranate and banana peels, cotton bolls, hazelnut shells, tobacco fibres, pine bark, and wheat shells were used as absorbents (Table 3 ).

The rate of adsorption was determined by selecting the initial $\mathrm{As}(\mathrm{V})$ concentration as $50 \mathrm{mg} / \mathrm{L}$ over variable time steps using pseudo first-order and pseudo secondorder kinetic models. Experiments regarding adsorption kinetics were used to study the transient behaviour of batch adsorption without considering the actual mechanism of pollutant transport. The linearized form of both the pseudo first-order and pseudo second-order kinetic models can be written using Eqs. (8) and (9), respectively.

$$
\begin{gathered}
\log \left(q_{e}-q_{t}\right)=\log q e-\frac{K_{1}}{2.303} t \\
\frac{t}{q_{t}}=\frac{1}{k_{2} q_{e}^{2}}+\frac{1}{q_{e}} t
\end{gathered}
$$

...where $\mathrm{q}_{e}$ is the amount of metal ions adsorbed at equilibrium per unit mass of adsorbent $(\mathrm{mg} / \mathrm{g}), \mathrm{q}_{\mathrm{t}}$ is the amount of metal adsorbed at time $\mathrm{t}\left(\mathrm{mg} / \mathrm{g}\right.$ ), and $\mathrm{K}_{1}$ (per hour) and $\mathrm{K}_{2}(\mathrm{~g} / \mathrm{mg} / \mathrm{min})$ are the adsorption rate constants for the pseudo first-order and the pseudo second-order kinetic models, respectively. A poor correlation with the experimental data was observed using an initial As(V) concentration of $50 \mathrm{mg} / \mathrm{L}$ in the pseudo first-order kinetic model as expressed by the $\mathrm{R}^{2}$ values (less than 0.9 ) in the plot of $\log \left(\mathrm{q}_{\mathrm{e}}-\mathrm{q}\right) \sim$ time (Fig. 14a).

On the other hand, $\mathrm{R}^{2}$ values close to unity were observed for all three adsorbents, which displayed a linear relationship at an initial $\mathrm{As}(\mathrm{V})$ concentration of $50 \mathrm{mg} / \mathrm{L}$, as shown in Fig. 14b). The values of the pseudo-secondorder rate constant $\left(\mathrm{K}_{2}, \mathrm{~g} / \mathrm{mg} / \mathrm{min}\right)$ and $\mathrm{q}_{\mathrm{e}}(\mathrm{mg} / \mathrm{g})$ were calculated using the slope and intercept values of the plot $\mathrm{t} / \mathrm{q}_{\mathrm{t}} \sim \mathrm{t}$, presented in Table 4 . The value of $\mathrm{q}_{\mathrm{e}}$ (cal) agreed with the experimental adsorption capacity (Table 4) at an initial $\mathrm{As}(\mathrm{V})$ concentration of $50 \mathrm{mg} / \mathrm{L}$, indicating that the pseudo second-order model is more likely to describe the kinetic behaviour of $\mathrm{As}(\mathrm{V})$ adsorption onto DPF, OP, and the hybrid adsorbent.
Table 3. Summary and comparison of the adsorption capacities

\begin{tabular}{|c|c|c|c|c|}
\hline Adsorbent & $\begin{array}{l}\mathrm{Cu}^{+2} \\
\text { uptake } \\
\mathrm{mg} / \mathrm{g}\end{array}$ & $\begin{array}{l}\mathrm{Pb}^{+2} \\
\text { uptake } \\
\mathrm{mg} / \mathrm{g}\end{array}$ & $\begin{array}{l}\text { As(V) } \\
\text { uptake } \\
\mathrm{mg} / \mathrm{g}\end{array}$ & $\begin{array}{l}\text { Refe- } \\
\text { rences }\end{array}$ \\
\hline Pomegranate peel & 1.31 & 13.87 & - & {$[60]$} \\
\hline Tea waste & 48 & 65 & - & {$[61]$} \\
\hline $\begin{array}{l}\text { Orange juice } \\
\text { residues }\end{array}$ & - & - & 132 & {$[62]$} \\
\hline Cotton boll & 11.40 & - & - & {$[63]$} \\
\hline Hazelnut shells & - & 28.18 & - & {$[64]$} \\
\hline Tobacco fibre & 10.5 & - & - & {$[65]$} \\
\hline $\begin{array}{c}\text { Moringa } \\
\text { oleifera } \\
\text { Lamarck seed }\end{array}$ & - & - & 2.14 & {$[66]$} \\
\hline Rice husks & 31.85 & - & - & {$[67]$} \\
\hline $\begin{array}{l}\text { Mucilaginous } \\
\text { leaves of DEP }\end{array}$ & - & 41.49 & - & {$[68]$} \\
\hline Coconut shells & - & - & 76.66 & [69] \\
\hline Wheat shells & 17.42 & - & - & [19] \\
\hline Banana peel & - & 5.71 & - & {$[70]$} \\
\hline Eggshells & 34.48 & 90.90 & - & {$[71]$} \\
\hline Orange peel & 3.65 & - & - & {$[72]$} \\
\hline Tea fungal biomass & - & - & 4.95 & [73] \\
\hline Pine bark & 9.46 & - & - & {$[74]$} \\
\hline DPF & 39.6 & 30 & 25 & \multirow{3}{*}{$\begin{array}{l}\text { Current } \\
\text { study }\end{array}$} \\
\hline OP & 50 & 43.5 & 34 & \\
\hline DPF-OP & 46 & 37.74 & 29 & \\
\hline
\end{tabular}
of different adsorbents.

After application of boundary conditions and integration, the pseudo second-order model can be expressed using Eq. (10).

$$
\left(\frac{t}{q_{t}}\right)=\frac{1}{k_{2} q^{2} e}
$$

Second order rate constants are used for the sorption rate using Eq. (11).

$$
h=k_{2} q^{2}
$$

The linearized form of the pseudo second-order model has been used for divalent metal adsorption onto adsorbents, and this model is based on solid-phase sorption $[38,75]$. The good fit of the pseudo secondorder model for the adsorption of $\mathrm{As}(\mathrm{V})$ on all three adsorbents supports the assumption that chemisorption is the rate-controlling step, which involves the exchange or sharing of electrons between adsorbent and adsorbate. 

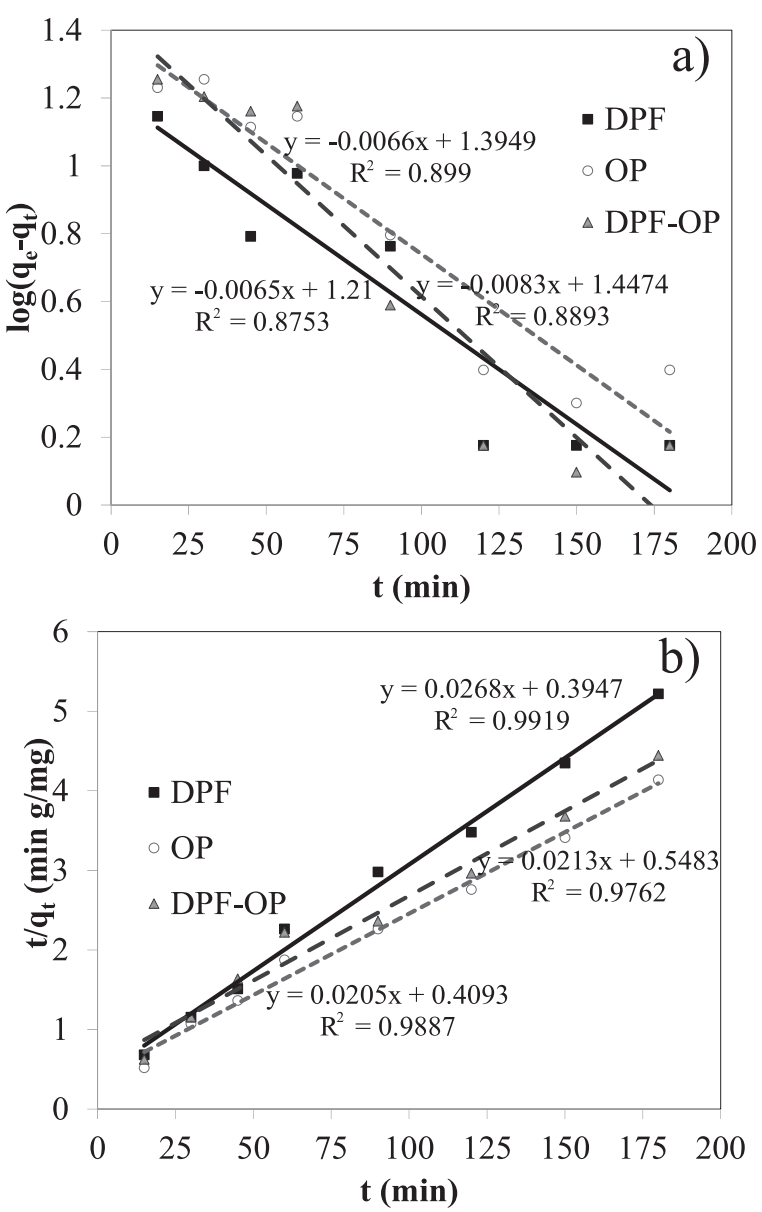

Fig. 14. Adsorption of As(V) on individual and hybrid adsorbents: a) pseudo first-order kinetic plot, b) pseudo second-order kinetic plot at $50 \mathrm{mg} / \mathrm{L}$ initial concentration of $\mathrm{As}(\mathrm{V})$.

Effects of Temperature and Thermodynamics

The adsorption capacities of As(V) on DPF, OP, and the hybrid material were evaluated at temperatures ranging from $30-50^{\circ} \mathrm{C}$ using an initial concentration of $50 \mathrm{mg} / \mathrm{L}$. As shown in Fig. 15, greater As(V) removal (approximately $16 \%$ ) was observed for DPF compared to the OP and DPFOP adsorbents (6-8\%) when the temperature of the aqueous solution was increased from 30 to $50^{\circ} \mathrm{C}$, which shows that temperature has a driving effect on the adsorption process. The adsorption capacity of DPF decreased from

Table 4. Pseudo-second-order models for $\mathrm{As}(\mathrm{V})$ adsorption on different adsorbents at $50 \mathrm{mg} / \mathrm{L}$ initial concentration of As(V).

\begin{tabular}{|c|c|c|c|c|c|}
\hline Adsorbent & $\begin{array}{c}\mathrm{q}_{\mathrm{e}} \\
\text { experiment } \\
(\mathrm{mg} / \mathrm{g})\end{array}$ & $\begin{array}{c}\mathrm{q}_{\mathrm{cal}} \\
(\mathrm{mg} / \mathrm{g})\end{array}$ & $\begin{array}{c}\mathrm{K}_{2} \\
(\mathrm{~g} / \mathrm{mg} / \mathrm{min})\end{array}$ & $\mathrm{h}$ & $\mathrm{R}^{2}$ \\
\hline DPF & 36 & 37.313 & 0.002 & 2.534 & 0.992 \\
\hline OP & 46 & 48.780 & 0.001 & 2.443 & 0.989 \\
\hline DPF-OP & 42 & 46.948 & 0.001 & 1.824 & 0.976 \\
\hline
\end{tabular}

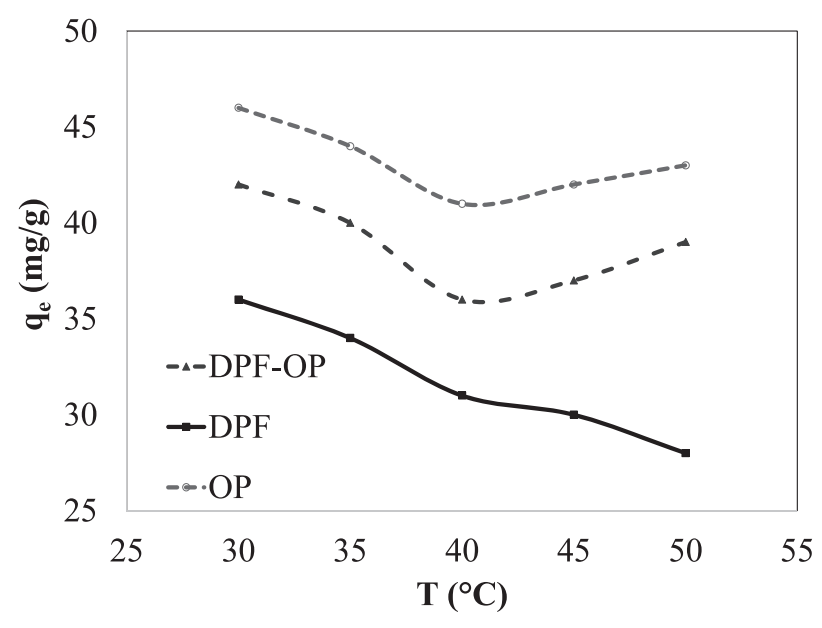

Fig. 15. Effects of temperature on adsorption capacity of different adsorbents for $\mathrm{As}(\mathrm{V})$.

36 to $28 \mathrm{mg} / \mathrm{g}$ after increasing the temperature from 30 to $50^{\circ} \mathrm{C}$, which suggests an exothermic chemical interaction between the adsorbent and the adsorbate [76]. However, both OP and DPF-OP displayed an exothermic adsorption process when temperatures increased from 30 to $40^{\circ} \mathrm{C}$, whereas an endothermic process was observed for temperatures ranging between $40-50^{\circ} \mathrm{C}$ (Fig. 15).

Thermodynamic parameters were determined to further assess the effects of temperature changes on $\mathrm{As}(\mathrm{V})$ adsorption capacity of different adsorbents (Table 5). The distribution coefficient of adsorption $\left(\mathrm{K}_{d}\right)$ can be calculated using Eq. (12):

$$
K_{d}=\frac{q_{e}}{C_{e}}
$$

...where $\mathrm{C}_{\mathrm{e}}$ is the concentration of $\mathrm{As}(\mathrm{V})$ in liquid phase and $\mathrm{q}_{\mathrm{e}}$ is the solid phase concentration at equilibrium. A Van't Hoff plot was used to calculate the change in the standard enthalpy, $\Delta \mathrm{H}(\mathrm{kJ} / \mathrm{mol})$, and entropy $\Delta \mathrm{S}(\mathrm{kJ} / \mathrm{mol})$ using Eq. (13):

$$
\ln K_{d}=-\frac{\Delta H}{\mathrm{R}}\left(\frac{1}{T}\right)+\frac{\Delta S}{R}
$$

...where $\mathrm{T}$ is the temperature $(\mathrm{K})$ and $\mathrm{R}$ is universal gas constant $(8.314 \mathrm{~J} / \mathrm{mol} / \mathrm{K})$. Finally, the values of Gibbs free energy change $(\Delta \mathrm{G}, \mathrm{kJ} / \mathrm{mol})$ were also calculated using Eq. (14):

$$
\Delta \mathrm{G}=\Delta \mathrm{H}-\mathrm{T} \Delta \mathrm{S}
$$

For DPF adsorbents, the negative value of $\Delta \mathrm{H}$ $(-0.011 \mathrm{KJ} / \mathrm{mol})$ showed that $\mathrm{As}(\mathrm{V})$ adsorption onto DPF is an exothermic reaction, while the positive value of $\Delta \mathrm{S}(0.04 \mathrm{KJ} / \mathrm{mol})$ confirmed the increased randomness at the solid solution interface. However, both OP and DPF-OP reflected both exothermic and endothermic adsorption reactions with negative and positive enthalpy values at temperatures ranging between $303-313 \mathrm{~K}$ and 
Table 5. Thermodynamic parameters of $\mathrm{As}(\mathrm{V})$ adsorption onto different adsorbents in the temperature range 303-323 K.

\begin{tabular}{|c|c|c|c|c|c|c|c|}
\hline \multirow{2}{*}{ Type of Adsorbent } & $\Delta \mathrm{H}$ & $\Delta \mathrm{S}$ & \multicolumn{5}{|c|}{$\Delta \mathrm{G}(\mathrm{KJ} / \mathrm{mol})$} \\
\cline { 2 - 8 } & $(\mathrm{KJ} / \mathrm{mol})$ & $(\mathrm{KJ} / \mathrm{mol})$ & $303 K$ & $308 K$ & $313 \mathrm{~K}$ & $318 \mathrm{~K}$ & $323 \mathrm{~K}$ \\
\hline DPF (303-323 K) & -0.011 & 0.04 & -12.13 & -12.33 & -12.53 & -12.73 & -12.93 \\
\hline OP (303-313 K) & -0.014 & 0.049 & -14.86 & -15.11 & -15.35 & & \\
\hline OP (313-323 K) & 0.005 & 0.013 & & & -4.06 & -4.13 & -4.19 \\
\hline DPF-OP (303-313 K) & -0.012 & 0.045 & -13.65 & -13.87 & -14.10 & & \\
\hline DPF-OP (313-323 K) & 0.004 & 0.01 & & & -3.13 & -3.18 & -3.23 \\
\hline
\end{tabular}

313-323 K, respectively, as shown in Table 5. Increased randomness at the solid-liquid interface was observed because of the positive values of $\Delta \mathrm{S}$, which, compared with the temperature range of 303-313 K, was lower in the temperature range of $313-323 \mathrm{~K}$ due to an increase in the adsorption in the latter range. Finally, negative values of $\Delta \mathrm{G}$ were observed at all temperatures (Table 5), confirming the fact that the adsorption of $\mathrm{As}(\mathrm{V})$ onto $\mathrm{DPF}, \mathrm{OP}$, and the hybrid material proceeded in the forward direction and was spontaneous in nature.

\section{Conclusions}

In this study, the use of DPF and OP as individual and hybrid materials for $\mathrm{Cu}^{+2}, \mathrm{~Pb}^{+2}$, and $\mathrm{As}(\mathrm{V})$ removal was investigated in detail. Batch experiments were performed in triplicate using fixed concentrations of 0.5 and $1 \mathrm{~g} / \mathrm{L}$ each of DPF or OP when used individually, and $0.5 \mathrm{~g} / \mathrm{L}$ each of DPF and OP for the hybrid adsorbent. With respect to equilibrium, no considerable changes in metal removal were observed after approximately 120 minutes, and equilibrium was achieved after 150 minutes. The removal efficiency of $\mathrm{Cu}^{+2}$ was higher than that of $\mathrm{Pb}^{+2}$. Regardless of the type of adsorbent, As(V) exhibited the lowest removal efficiencies. A slightly higher removal efficiency of metal ions using OP could be attributed to the increased functional groups on the chemically pre-treated adsorbent. The highest removal was observed at a $\mathrm{pH}$ of 5-6 in most cases, confirming the interference of $\mathrm{H}^{+}$ions and minimal adsorption at high $\mathrm{pH}$ values.

The adsorption data revealed a linear increase in metal removal capacities with increasing adsorbent concentrations from 0.1 up to $2 \mathrm{~g} / \mathrm{L}$; however, slightly better results were achieved using OP alone, compared to DPF or the hybrid adsorbents. Significantly higher removal was observed with a $45 \mu \mathrm{m}$ particle size compared to the largest particle size $(251 \mu \mathrm{m})$, mainly due to the large surface area of the small-sized particles. Finally, a decrease of $30-40 \%$ in removal efficiency was observed for all three heavy metal ions using DPF or the hybrid adsorbent by increasing initial metal concentrations from 20 to $80 \mathrm{mg} / \mathrm{L}$, mainly due to saturation of sorption sites at the surface of the adsorbent. Comparing adsorption isotherms, the Freundlich model agreed with the experimental data slightly better than the Langmuir model for both DPF and the hybrid adsorbent. A poor correlation with the experimental data was observed using the pseudo first-order kinetic model. The adsorption capacity of DPF decreased by increasing the temperature from 30 to $50^{\circ} \mathrm{C}$, which supports the exothermic nature of the adsorption process (negative value of $\Delta \mathrm{H}$ ), while the positive value of $\Delta \mathrm{S}$ confirms the increased randomness at the solid-solution interface for $\mathrm{As}(\mathrm{V})$ adsorption. On the other hand, both $\mathrm{OP}$ and DPF-OP displayed exothermic and endothermic adsorption properties and increased randomness at the solid-liquid interface. The adsorption of $\mathrm{As}(\mathrm{V})$ onto the studied adsorbents proceeded in the forward direction and was spontaneous in nature, as concluded from the negative $\Delta \mathrm{G}$ values.

The results illustrated the successful application of DPF, OP, and the hybrid adsorbent for the adsorption of heavy metal ions and confirmed the possibility of using these agricultural wastes as adsorbing materials in individual as well as hybrid forms. The enhanced performance of chemically pre-treated hybrid material compared with DPF further supported the idea that suitable modifications and combinations will result in increasing the number of functional groups on the adsorbent surface. As such, naturally occurring interacting functional groups can be made available for the adsorption of wastewater that contains multiple heavy metals, which may influence the removal of a particular metal.

\section{Acknowledgements}

This work was supported by project No. 150215, funded by the scientific research deanship at King Faisal University (KFU). The authors acknowledge and express their gratitude for the support received from the Alamoudi Water Research Chair at King Saud University, Riyadh, Saudi Arabia.

\section{References}

1. PENG S.H., WANG W.X., LI X., YEN Y.F. Metal partitioning in river sediments measured by sequential extraction and biomimetic approaches. Chemosphere 57, 839, 2004.

2. KHAN S., CAO Q., ZHENG Y.M., HUANG Y. Z., ZHU Y.G. Health risks of heavy metals in contaminated soils 
and food crops irrigated with wastewater in Beijing, China. Environ. Pollut. 152, 686, 2008.

3. SUD D., MAHAJAN G., KAUR M.P. Agricultural waste material as potential adsorbent for sequestering heavy metal ions from aqueous solutions - A review. Bioresour. Technol. 99, 6017, 2008.

4. HLIHOR R.M., GAVRILESCU M. Removal of some environmentally relevant heavy metals using low-cost natural sorbents. Environ. Eng. Manage. J. 8, 353, 2009.

5. JAMIL M., ZIA M.S., QASIM M. Contamination of agroecosystem and human health hazards from wastewater used for irrigation. J. Chem. Soc. Pak. 32, 370, 2010.

6. SINGH A., SHARMA R.K., AGRAWAL M., MARSHALL F.M. Health risk assessment of heavy metals via dietary intake of foodstuffs from the wastewater irrigated site of a dry tropical area of India. Food Chem. Toxicol. 48, 611, 2010.

7. HOSSAIN M.A., NGO H.H., GUO W.S. Performance of cabbage and cauliflower wastes for heavy metals removal. Desalin. Water Treat. 52, 844, 2014.

8. VARGA M., TAKÁCS M., ZÁRAY G., VARGA I. Comparative study of sorption kinetics and equilibrium of chromium (VI) on charcoals prepared from different lowcost materials. Microchem. J. 107, 25, 2013.

9. PAMUKOGLU M.Y., KARACHI F. Removal of copper (II) ions from aqueous medium by absorption onto powdered waste sludge. Process Biochem. 41, 1047, 2006.

10. GUPTA V.K., RASTOGI A. Absorption of lead from aqueous solutions by green algae Spirogyra species: Kinetics and equilibrium studies. J. Hazard Mater. 152, 407, 2008

11. POPESCU G., DUMITRU T. Biosorption of some heavy metals from media with high salt concentrations by Halophilic archaea. Biotechnol. Biotechnol. Equip. 23, 791, 2009.

12. FU F., WANG Q. Removal of heavy metal ions from wastewaters: A review. J. Environ. Manage. 92, 407, 2011.

13. RATHINAM A., MAHARSHI B., JANARDHANAN S.K., JONNALAGADDA R.R., NAIR B.U. Biosorption of cadmium metal ion from simulated wastewaters using Hypnea Valencia biomass: A kinetic and thermodynamic study. Bioresour. Technol. 101, 1466, 2010.

14. AUTA M., HAMEED B.H. Coalesced Chitosan activated carbon composite for batch and fixed-bed adsorption of cationic and anionic dyes. Colloids Surf. B. 105, 199, 2013.

15. GALÁN J., RODRÍGUEZ A., GÓMEZ J.M., ALLEN S.J., WALKER G.M. Reactive dye adsorption onto a novel mesoporous carbon. Chem. Eng. J. 219, 62, 2013.

16. ISMAIL B., HUSSAIN S.T., AKRAM S. Adsorption of methylene blue onto spinel magnesium aluminate nanoparticles: Adsorption isotherms, kinetic and thermodynamic studies. Chem. Eng. J. 219, 395, 2013.

17. UZUNOĞLU D., GUREL N., OZKAYA N., OZER A. The single batch absorption of copper (II) ions on Sargassum acinarum. Desalin. Water Treat. 52, 1514, 2014.

18. AL BSOUL A., ZEATOUN L., ABDELHAY A., CHIHA M. Adsorption of copper ions from water by different types of natural seed materials. Desalin. Water Treat. 52, 5876, 2014.

19. AYDIN H., BULUT Y., YERLIKAYA C. Removal of copper (II) from aqueous solution by adsorption onto low-cost adsorbents. J. Environ. Manage. 87, 37, 2008.

20. PUTRA W.P., KAMARI A., YUSOFF S.N.M., ISHAK C.F., MAHAMED A., HASHIM N., ISA I.M. Biosorption of $\mathrm{Cu}$ (II), $\mathrm{Pb}$ (II) and $\mathrm{Zn}$ (II) Ions from Aqueous Solutions Using Selected Waste Materials: Adsorption and Characterisation Studies. J. Encapsulation Adsorpt. Sci. 04, 25, 2014.
21. HSU T.C. Experimental assessment of adsorption of $\mathrm{Cu}^{2+}$ and $\mathrm{Ni}^{2+}$ from aqueous solution by oyster shell powder. $\mathrm{J}$. Hazard Mater. 171, 995, 2009.

22. XUEYAN G., ZHANG S., SHAN X.Q. Adsorption of metal ions on lignen. J. Hazard. Mater. 151, 134, 2008.

23. ERTUGAY N., BAYHAN Y.K. The removal of copper (II) ion by using mushroom biomass (Agaricus bisporus) and kinetic modelling. Desalination 255, 137, 2010.

24. CIESIELCZYK F., BARTCZAK P., JESIONOWSKI T. Removal of nickel(II) and cadmium(II) ions from aqueous solutions using an oxide adsorbent of $\mathrm{MgO} \cdot \mathrm{SiO}_{2}$ type. Desalin. Water Treat. 55 (5), 1271, 2015.

25. KLAPISZEWSKI L., BARTCZAK P., WYSOKOWSKI M., JANKOWSKA M., KABAT K., JESIONOWSKI T. Silica conjugated with kraft lignin and its use as a novel 'green' sorbent for hazardous metal ions removal. Chem. Eng. J. 260, 684, 2015

26. JUSOH A., SU SHIUNG L., ALI N.A., NOOR M.J.M.M. A simulation study of the removal efficiency of granular activated carbon on cadmium and lead. Desalination 206, 9, 2007.

27. KANG K.C., KIM S.S., CHOI J.W., KWON S.H. Sorption of $\mathrm{Cu}$ (II) and $\mathrm{Cd}$ (II) onto acid and base-pretreated granular activated carbon and activated carbon fiber samples. J. Ind. Eng. Chem. 14, 131, 2008.

28. KURNIAWAN T.A., CHAN G.Y.S., LO W., BABEL S. Comparisons of low-cost adsorbents for treating wastewaters laden with heavy metals. Sci. Total Environ. 366, 409, 2006.

29. CHIBAN M., CARJA G., LEHUTU G., SINAN F. Equilibrium and thermodynamic studies for the removal of As (V) ions from aqueous solution using dried plants as adsorbents. Arab J. Chem. In press (doi:10.1016/j. arabjc.2011.10.002), 2011.

30. ALTAHER H. Preliminary study of the effect of using biosorbents on the pollution of the treated water. Global Nest J. 16 (4), 707, 2014.

31. BARTCZAK P., NORMAN M., KLAPISZEWSKI L., KARWAŃSKA N., KAWALEC M., BACZYŃSKA M., WYSOKOWSKI M., ZDARTA J., CIESIELCZYK F., JESIONOWSKI T. Removal of nickel(II) and lead(II) ions from aqueous solution using peat as a low-cost adsorbent: A kinetic and equilibrium study. Arabian J. Chem. In press (doi:10.1016/j.arabjc.2015.07.018), 2015.

32. HALEEM A.M., ABDULGAFOOR E.A. The Biosorption of $\mathrm{Cr}(\mathrm{VI})$ From Aqueous Solution Using Date Palm Fibers (Leef). Al-Khwarizmi Eng. J. 6, 31, 2010.

33. AL-HAIDARY A.M.A., ZANGANAH F.H.H., AL-ZAWI S.R.F. KHALILI F.I., AL-DUJAILI A.H. A Study on Using Date Palm Fibers and Leaf Base of Palm as Adsorbents for $\mathrm{Pb}$ (II) Ions from Its Aqueous Solution. Water Air Soil Poll. 214, 73, 2011.

34. BELALA Z., JEGUIRIM M., BELHACHEMI M. Biosorption of copper from aqueous solutions by date stones and palm-trees waste. Environ. Chem. Lett. 9, 65, 2011.

35. BOUDRAHEM F., AISSANI-BENISSAD F., SOUALAH A. Adsorption of Lead(II) from Aqueous Solution by Using Leaves of Date Trees As an Adsorbent. J. Chem. Eng. Data 56, 1804, 2011.

36. GHORBANI F., SANATI A.M., YOUNESI H., GHOREYSHI A.A. The potential of date-palm leaf ash as low-cost adsorbent for the removal of $\mathrm{Pb}$ (ii) ion from aqueous solution. Int. J. Eng. Trans. B Appl. 25, 269, 2012.

37. AL-GHAMDI A., ALTAHER H., OMAR W. Application of date palm trunk fibers as adsorbents for removal of $\mathrm{Cd}^{+2}$ 
ions from aqueous solutions. J. Water Reuse. Desal. 3, 47, 2013.

38. LIANG S., GUO X., FENG N., TIAN Q. Effective removal of heavy metals from aqueous solutions by orange peel xanthate. Trans. Nonferrous Met. Soc. China 20, 187, 2010.

39. GUPTA V.K., NAYAK A. Cadmium removal and recovery from aqueous solutions by novel adsorbents prepared from orange peel and $\mathrm{Fe}_{2} \mathrm{O}_{3}$ nanoparticles. Chem Eng J. 180, 81, 2012.

40. LASHEEN M.R., AMMAR N.S., IBRAHIM H.S. Adsorption/desorption of $\mathrm{Cd}(\mathrm{II}), \mathrm{Cu}(\mathrm{II})$ and $\mathrm{Pb}(\mathrm{II})$ using chemically modified orange peel. Equilibrium and kinetic studies. Solid State Sci. 14, 202, 2012.

41. MACEDO S., OTUBO L., FERREIRA O.P., GIMENEZ I.F., MAZALI I. O., BARRETO L.S. Biomorphic activated porous carbons with complex micro- structures from lignocellulosic residues. Micropor. Mesopor. Mat. 107, 276, 2008.

42. VANSANT E.F., VOORT P.V.D., VRANCKEN K.C. Characterization and Chemical Modification of the Silica Surface. Elsevier, Netherlands, 1995.

43. GEBREHAWARIA G., HUSSEN A., RAO V.M. Removal of hexavalent chromium from aqueous solutions using barks of Acacia albida and leaves of Euclea schimperi. Int. J. Environ. Sci. Technol. 12, 1569, 2015.

44. ZHANG Z., O'HARA I.M., KENT G.A., DOHERTY W.O.S. Comparative study on adsorption of two cationic dyes by milled sugarcane bagasse. Ind. Crops Prod. 42, 41, 2013.

45. GHIMIRE K.N., INOUE K., YAMAGUCHI H., MAKINO K., MIYAJIMA T. Adsorptive separation of arsenate and arsenite anions from aqueous medium by using orange waste. Water Res. 37, 4945, 2003

46. GUIBAUD G., TIXIER N., BOUJU A., BAUDU M. Relation between extracellular polymers' composition and its ability to complex $\mathrm{Cd}, \mathrm{Cu}$ and $\mathrm{Pb}$. Chemosphere 52, 1701, 2003.

47. KRISHNAN K.A., ANIRUDHAN T.S. Removal of cadmium (II) from aqueous solutions by steam-activated sulphurised carbon prepared from sugar cane bagasse pith: kinetics and equilibrium studies. Water SA. 29 (2), 147, 2003.

48. HO Y.S., NG J.C.Y., MCKAY G. Kinetics of pollutant sorption by biosorbents: review. Sep. Purif. Rev. 29 (2), 189, 2000.

49. QADEER R., AKHTAR S. Kinetics study of lead ion adsorption on active carbon. Turk. J. Chem. 29, 95, 2005.

50. ABIA A.A., HORSFALL M., DIDI O. Studies on the use of agricultural by-product for the removal of trace metals from aqueous solutions. J. Appl. Sci. Environ. Manage. 6 (2), 89, 2002.

51. ARECO M.M., DOS SANTOS A.M. Copper, zinc, cadmium and lead biosorption by Gymnogongrus torulosus. Thermodynamics and kinetics studies. Colloids Surf. B. 81, $620,2010$.

52. EL-BINDARY A.A., HUSSIEN M.A., DIAB M.A., EESSA A.M. Adsorption of Acid Yellow 99 by polyacrylonitrile/ activated carbon composite: Kinetics, thermodynamics and isotherm studies. J. Mol. Liq. 197, 236, 2014.

53. CHIENG H.I., LIM L.B.L., PRIYANTHA N. Enhancing adsorption capacity of toxic malachite green dye through chemically modified breadnut peel: equilibrium, thermodynamics, kinetics and regeneration studies. Environ. Technol. 36, 86, 2015.

54. AL-GHOUTI M.A., LI J., SALAMH Y., AL-LAQTAH N., WALKER G., AHMAD M.N.M. Adsorption mechanisms of removing heavy metals and dyes from aqueous solution using date pits solid adsorbent. J. Hazard. Mater. 176 (1-3), 510,2010

55. AL-HOMAIDAN A.A., AL-HOURI H.J., AL-HAZZANI A.A., ELGAALY G., MOUBAYED N.M.S. Biosorption of copper ions from aqueous solutions by Spirulina platensis biomass. Arab. J. Chem. 7, 57, 2014.

56. HAMEED B.H., CHIN L.H., RENGARAJ S. Adsorption of 4-chlorophenol onto activated carbon prepared from rattan sawdust. Desalination 225, 185, 2008.

57. REHMAN M.S., KIM I., HAN J.-I. Adsorption of methylene blue dye from aqueous solution by sugar extracted spent rice biomass. Carbohydr. Polym. 90, 1314, 2012.

58. TAHIR S.S., RAUF N. Removal of a cationic dye from aqueous solutions by adsorption onto bentonite clay. Chemosphere 63, 1842, 2006.

59. AHMARUZZAMAN M., GAYATRI S.L. Activated Tea Waste as a Potential Low-Cost Adsorbent for the Removal of p-Nitrophenol from Wastewater. J. Chem. Eng. Data 55, 4614, 2010.

60. EL-ASHTOUKHY E.-S.Z., AMIN N.K., ABDELWAHAB O. Removal of lead (II) and copper (II) from aqueous solution using pomegranate peel as a new adsorbent. Desalination, European Desalination Society and Center for Research and Technology Hellas (CERTH), Sani Resort 22-25 April 2007, Halkidiki, GreeceEuropean Desalination Society and Center for Research and Technology Hellas (CERTH), Sani Resort 223, 162, 2008

61. AMARASINGHE B.M.W.P.K., WILLIAMS R.A. Tea waste as a low cost adsorbent for the removal of $\mathrm{Cu}$ and $\mathrm{Pb}$ from wastewater. Chem. Eng. J. 132, 299, 2007.

62. GHIMIRE K.N., INOUE K., MAKINO K., MIYAJIMA T. Adsorptive Removal of Arsenic Using Orange Juice Residue. Sep. Sci. Technol. 37, 2785, 2002.

63. OZSOY H.D., KUMBUR H. Adsorption of $\mathrm{Cu}(\mathrm{II})$ ions on cotton boll. J. Hazard. Mater. 136, 911, 2006

64. PEHLIVAN E., ALTUN T., CETIN S., BHANGER M.I. Lead sorption by waste biomass of hazelnut and almond shell. J. Hazard. Mater. 167, 1203, 2009.

65. DEMIRBAS A. Heavy metal adsorption onto agro-based waste materials: A review. J. Hazard. Mater. 157, 220, 2008.

66. FELICITOS N.A., SMITH K. An Eco-Friendly approach to remove Arsenic from Agricultural waste. J. Environ. Researh Dev. 1, 331, 2007.

67. WONG K.K., LEE,C.K., LOW K.S., HARON M.J. Removal of $\mathrm{Cu}$ and $\mathrm{Pb}$ from electroplating wastewater using tartaric acid modified rice husk. Process Biochem. 39, 437, 2003.

68. EDOKPAYI J.N., ODIYO J.O., MSAGATI T.A.M., POPOOL, E.O. A Novel Approach for the Removal of Lead(II) Ion from Wastewater Using Mucilaginous Leaves of Diceriocaryum eriocarpum Plant. Sustainability 7, 14026, 2015.

69. KIKUCHI Y., QIAN Q., MACHIDA M., TATSUMOTO $\mathrm{H}$. Effect of $\mathrm{ZnO}$ loading to activated carbon on $\mathrm{Pb}$ (II) adsorption from aqueous solution. Carbon 44, 195, 2006.

70. ANWAR J., SHAFIQUE U., WAHEED-UZ-ZAMAN, SALMAN M., DAR A., ANWAR S. Removal of Pb(II) and $\mathrm{Cd}(\mathrm{II})$ from water by adsorption on peels of banana. Bioresour. Technol. 101, 1752, 2010.

71. PUTRA W.P., KAMARI A., YUSOFF S.N.M., ISHAK C.F., MOHAMED A., HASHIM N., ISA I.M. Biosorption of $\mathrm{Cu}$, (II), $\mathrm{Pb}(\mathrm{II}), \mathrm{Ni}(\mathrm{II})$, and $\mathrm{Fe}(\mathrm{II})$ on Alkali Treated Coir Fibers. Sep. Sci. Technol. 48, 421, 2013.

72. AJMAL M., RAO R.A.K., AHMAD R., AHMAD J. Adsorption studies on Citrus reticulata (fruit peel of orange): removal and recovery of $\mathrm{Ni}(\mathrm{II})$ from electroplating wastewater. J. Hazard. Mater. 79, 117, 2000. 
73. HOSSAIN M.F. Arsenic contamination in Bangladesh-An overview. Agric. Ecosyst. Environ. 113, 1, 2006.

74. REDDAD Z., GERENTE C., ANDRES Y., LE CLOIREC P. Adsorption of Several Metal Ions onto a Low-Cost Biosorbent: Kinetic and Equilibrium Studies. Environ. Sci. Technol. 36, 2067, 2002.
75. YADAV S. K., SINGH D.K., SINHA S. Adsorption study of lead(II) onto xanthated date palm trunk: kinetics, isotherm and mechanism. Desalin. Water Treat. 51, 6798, 2013.

76. NABIL G.M., EL-MALLAH N.M., MAHMOUD M.E. Enhanced decolorization of reactive black 5 dye by active carbon sorbent-immobilized-cationic surfactant (AC-CS). J. Ind. Eng. Chem. 20 (3), 994, 2014. 
